\title{
Management of noninfectious posterior uveitis with intravitreal drug therapy
}

\author{
This article was published in the following Dove Press journal: \\ Clinical Ophthalmology \\ 13 October 2016 \\ Number of times this article has been viewed
}

\author{
Hui Yi Tan' \\ Aniruddha Agarwal ${ }^{2}$ \\ Cecilia S Lee ${ }^{3}$ \\ Jay Chhablani ${ }^{4}$ \\ Vishali Gupta ${ }^{5}$ \\ Manoj Khatri ${ }^{6}$ \\ Jayabalan Nirmal ${ }^{7}$ \\ Carlos Pavesio ${ }^{8}$ \\ Rupesh Agrawal ${ }^{1,7-9}$ \\ 'Yong Loo Lin School of Medicine, \\ National University of Singapore, \\ Singapore; ${ }^{2}$ Department of \\ Vitreoretina, Stanley M Truhlsen Eye \\ Institute, University of Nebraska \\ Medical Center, Omaha, NE, \\ ${ }^{3}$ Department of Ophthalmology, \\ University of Washington, Seattle, WA, \\ USA; ${ }^{4}$ Department of Vitreoretina, \\ LV Prasad Eye Institute, Hyderabad, \\ Telangana, ${ }^{5}$ Department of Retina \\ and Uvea, Post Graduate Institute \\ of Medical Education and Research, \\ Chandigarh, ${ }^{6}$ Department of Retina, \\ Rajan Eye Care Hospital, Chennai, \\ Tamil Nadu, India; ${ }^{7}$ School of \\ Material Science and Engineering, \\ Nanyang Technological University, \\ Singapore; ${ }^{8}$ Department of Medical \\ Retina, Moorfields Eye Hospital, \\ NHS Foundation Trust, London, UK; \\ ${ }^{9}$ Department of Ophthalmology, \\ National Healthcare Group Eye \\ Institute, Tan Tock Seng Hospital, \\ Singapore
}

Correspondence: Rupesh Agrawal Department of Ophthalmology, National Healthcare Group Eye Institute, Tan Tock Seng Hospital, I I Jalan Tan Tock Seng, Singapore 308433

Email rupesh_agrawal@ttsh.com.sg

\begin{abstract}
Uveitis is an important cause of vision loss worldwide due to its sight-threatening complications, especially cystoid macular edema, as well as choroidal neovascularization, macular ischemia, cataract, and glaucoma. Systemic corticosteroids are the mainstay of therapy for noninfectious posterior uveitis; however, various systemic side effects can occur. Intravitreal medication achieves a therapeutic level in the vitreous while minimizing systemic complications and is thus used as an exciting alternative. Corticosteroids, antivascular endothelial growth factors, immunomodulators such as methotrexate and sirolimus, and nonsteroidal anti-inflammatory drugs are currently available for intravitreal therapy. This article reviews the existing literature for efficacy and safety of these various options for intravitreal drug therapy for the management of noninfectious uveitis (mainly intermediate, posterior, and panuveitis).
\end{abstract}

Keywords: intravitreal therapy, noninfectious uveitis, posterior uveitis, intravitreal steroids, intravitreal methotrexate

\section{Introduction}

Uveitis is an important cause of vision loss worldwide and is the third leading cause of vision loss in developed countries. ${ }^{1,2}$ Uveitis is classified on the basis of the location of inflammation into anterior (iritis, iridocyclitis, and anterior cyclitis), intermediate (pars planitis, posterior cyclitis, and hyalitis), and posterior (focal, multifocal, or diffuse choroiditis, chorioretinitis, retinitis, and neuroretinitis). Panuveitis involves the inflammation of the anterior chamber, vitreous, retina, and choroid. Anterior uveitis is the most commonly encountered entity, and posterior uveitis constitutes $15 \%-22 \%$ of all cases of uveitis. Posterior uveitis is the most difficult to treat due to challenges encountered in delivering efficacious levels of therapeutic agents and can lead to visual morbidity. ${ }^{3}$

The goals of therapy in noninfectious uveitis (NIU) are to control inflammation, minimize recurrences, and prevent the occurrence of sight-threatening complications secondary to the disease or the therapy itself. The sight-threatening complications of chronic NIU include cystoid macular edema (CME) and choroidal neovascularization (CNV), with CME being the most common. ${ }^{4}$

Currently, systemic immunomodulation with oral corticosteroids is the mainstay of treatment to control the inflammation. Systemic steroid sparing immunomodulators such as antimetabolites (methotrexate, azathioprine, and mycophenolate mofetil) and calcineurin inhibitors (cyclosporine and tacrolimus), among others, are often included in the treatment plan. ${ }^{5}$

Although oral corticosteroids and immunomodulatory therapy are able to effectively control inflammation in the eyes, a number of systemic and ocular side effects 
Table I Studies on intravitreal triamcinolone (demographics)

\begin{tabular}{|c|c|c|c|c|c|c|}
\hline \multirow[t]{2}{*}{ Study } & \multirow[t]{2}{*}{ Period of study } & \multirow[t]{2}{*}{ Study design } & \multirow[t]{2}{*}{ Study duration } & \multirow{2}{*}{$\begin{array}{l}\text { Number of } \\
\text { participants/ } \\
\text { eyes }\end{array}$} & \multicolumn{2}{|c|}{ Demographics } \\
\hline & & & & & $\begin{array}{l}\text { Age } \\
\text { (years) }\end{array}$ & $\begin{array}{l}\text { Sex } \\
\text { (female) }\end{array}$ \\
\hline Kok et al ${ }^{8}$ & - & $\begin{array}{l}\text { Retrospective } \\
\text { noncomparative } \\
\text { (nonrandomized, } \\
\text { uncontrolled) } \\
\text { interventional case series }\end{array}$ & $\begin{array}{l}\text { Mean } 8.0 \text { months } \\
\text { (range, } 3-51 \text { months) }\end{array}$ & $\begin{array}{l}65 \text { eyes of } \\
54 \text { patients }\end{array}$ & $\begin{array}{l}44 \pm 15 \text { (range, } \\
14-76)\end{array}$ & - \\
\hline Park et al ${ }^{9}$ & $\begin{array}{l}\text { July } 2005 \text { to } \\
\text { February } 20 \mathrm{II}\end{array}$ & $\begin{array}{l}\text { Retrospective consecutive } \\
\text { case series }\end{array}$ & Follow-up $>24$ months & $\begin{array}{l}49 \text { eyes of } \\
49 \text { patients }\end{array}$ & $\begin{array}{l}38.6 \pm 9.8 \\
\text { (range, } 20-68 \text { ) }\end{array}$ & $38.80 \%$ \\
\hline Tuncer et $\mathrm{al}^{10}$ & $\begin{array}{l}\text { November } 2002 \\
\text { to April } 2006\end{array}$ & $\begin{array}{l}\text { Retrospective consecutive } \\
\text { case series }\end{array}$ & $\begin{array}{l}\text { Mean follow-up } 28 \text { months } \\
\text { (range, 9-50 months) }\end{array}$ & $\begin{array}{l}18 \text { eyes of } \\
15 \text { patients }\end{array}$ & $\begin{array}{l}24.7 \pm 6.0 \\
\text { (range, 17-36) }\end{array}$ & $27 \%$ \\
\hline Sallam et $\mathrm{al}^{\prime \prime}$ & - & $\begin{array}{l}\text { Retrospective consecutive } \\
\text { case series }\end{array}$ & Follow-up $\geq 3$ months & $\begin{array}{l}41 \text { eyes of } \\
35 \text { patients }\end{array}$ & - & - \\
\hline
\end{tabular}

Notes: Data presented as mean \pm SD. “-”, data not available.

are associated with their prolonged usage, which present a significant challenge in treating NIU. ${ }^{6}$ Additionally, topical corticosteroids may not reach the intermediate and posterior portions of the eye in therapeutic concentrations due to poor penetration to the posterior segment of the eye. ${ }^{7}$ With intravitreal corticosteroids, the drug is able to effectively reach the target area with the benefit of avoiding systemic side effects. In unilateral uveitis, intravitreal agents can be considered a safe and effective alternative to systemic immunosuppression. However, intravitreal steroids are commonly associated with raised intraocular pressure (IOP) and cataract formation, apart from the risks related to the intravitreal procedure itself such as endophthalmitis. Therefore, the use of alternate drugs for intravitreal therapy targeting different inflammatory pathways is being continuously explored.

This article reviews the current forms of intravitreal drug therapy for the treatment of NIU, and a summary of various forms of intravitreal therapy is provided in Tables 1-4.

\section{Methods}

In this study, English literature in PubMed, MEDLINE, and Cochrane databases was searched. The search included randomized trials and observational studies, comprised of prospective and retrospective cohort studies, case series, and case-control studies that evaluated the use of intravitreal therapy in the treatment of NIU. It also included preclinical studies for drugs, which have not undergone clinical trials. Studies with a sample size of $<15$ or pediatric population or animal studies for which human studies were present were excluded. The search was conducted with the following terminology: ((("Uveitis/therapy" [Mesh] OR "Uveitis, Intermediate/therapy" [Mesh]) OR "Uveitis, Posterior/ therapy" [Mesh]) OR "Uveitis, Anterior/therapy" [Mesh])
AND ("Intravitreal Injections" [Mesh] OR "Drug implants" [Mesh]). This yielded a total of 201 papers from PubMed. A search of "Uveitis" and ("therapy" or "treatment") and ("intravitreal injections" or "drug implants") on Cochrane yielded 49 trials. References obtained from these articles were hand-searched to identify relevant literature (Figure 1).

\section{Intravitreal agents for noninfectious posterior uveitis Intravitreal corticosteroids}

Currently, there are various methods to deliver corticosteroids to the vitreous and retina: intravitreal triamcinolone acetonide (IVTA) (Triesence ${ }^{\circledR}$ [Alcon, Ft Worth, TX, USA] and Trivaris ${ }^{\circledR}$ [Allergan, Riverside, CA, USA], which are approved by the US Food and Drug Administration [FDA] for intraocular use, and off-label Kenalog ${ }^{\circledR} 40$ [BristolMyers Squibb, Princeton, NJ, USA]), as well as intraocular drug implants: $0.7 \mathrm{mg}$ dexamethasone implant $\left(\right.$ Ozurdex $^{\circledR}$; Allergan Inc., Irvine, CA, USA), $0.59 \mathrm{mg}$ fluocinolone acetonide implant (FAi) (Retisert $^{\circledR}$; Bausch \& Lomb Inc., Rochester, NY, USA), and 0.019 mg FAi (ILUVIEN ${ }^{\circledR}$; Alimera Sciences Limited, Aldershot, UK).

\section{IVTA injection}

IVTA is able to effectively deliver corticosteroids to the vitreous and retina while avoiding the side effects associated with systemic therapy. Studies on IVTA have mainly evaluated its effect on uveitic CME as well as Behçet's disease. Tables 1-4 provide the summary of studies regarding IVTA.

In a retrospective noncomparative interventional case series of 65 eyes, Kok et al reported the effects of $4 \mathrm{mg} / 0.1 \mathrm{~mL}$ IVTA on uveitic CME in the short term. ${ }^{8}$ It was found that best-corrected visual acuity (BCVA) improved at a mean 


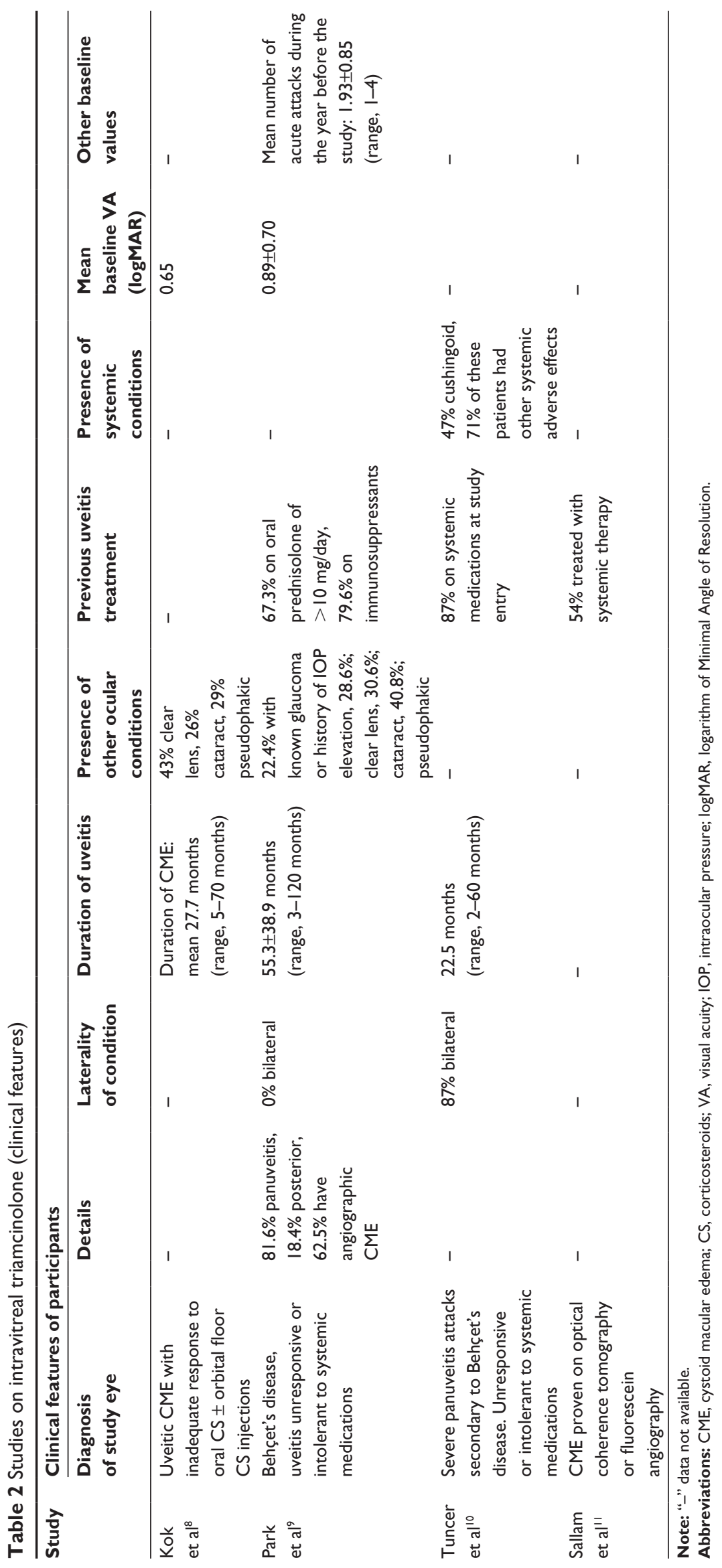


Table 3 Studies on intravitreal triamcinolone (outcomes)

\begin{tabular}{|c|c|c|c|c|c|c|}
\hline \multirow[t]{2}{*}{ Study } & \multirow{2}{*}{$\begin{array}{l}\text { Number of } \\
\text { participants/eyes }\end{array}$} & \multicolumn{3}{|l|}{ Intervention } & \multirow{2}{*}{$\begin{array}{l}\text { Numbers excluding } \\
\text { those lost to } \\
\text { follow-up/dropout }\end{array}$} & \multirow{2}{*}{$\begin{array}{l}\text { Outcomes measured } \\
\text { BCVA }\end{array}$} \\
\hline & & IVTA & Systemic CS & Immunosuppression & & \\
\hline $\begin{array}{l}\text { Kok } \\
\text { et } \text { al }^{8}\end{array}$ & $\begin{array}{l}65 \text { eyes of } \\
54 \text { patients }\end{array}$ & $4 \mathrm{mg} / 0.1 \mathrm{~mL}$ & \pm & \pm & Nil & $\begin{array}{l}0.39(P<0.005) \text {. Mean } \\
\text { improvement in VA only } \\
\text { statistically significant in } \\
\text { those } \leq 60 \text {. Best BCVA at } \\
4 \text { weeks. No change in } \\
16.9 \% \text { of eyes }\end{array}$ \\
\hline $\begin{array}{l}\text { Park } \\
\text { et al }{ }^{9}\end{array}$ & $\begin{array}{l}49 \text { eyes of } \\
49 \text { patients }\end{array}$ & $4 \mathrm{mg} / 0.1 \mathrm{~mL}$ & \pm & \pm & - & $\begin{array}{l}3 \text { months: } 0.59 \pm 0.55 \text {, } \\
6 \text { months: } 0.60 \pm 0.58 \text {, } \\
\text { I } 2 \text { months: } 0.70 \pm 0.65 \\
\text { I8 months: } 0.62 \pm 0.60 \\
24 \text { months: } 0.64 \pm 0.72 \text {, } \\
\text { Final visits: } 0.68 \pm 0.79 \\
\text { (all } P<0.00 \text { I). BCVA } \\
\text { improvement rate of } \geq 3 \text { lines } \\
\text { from baseline: } 40.8 \% \text { at } \\
6 \text { months, } 42.9 \% \text { at } \\
12 \text { months, } 38.8 \% \text { at } \\
24 \text { months }\end{array}$ \\
\hline $\begin{array}{l}\text { Tuncer } \\
\text { et al }\end{array}$ & $\begin{array}{l}18 \text { eyes of } \\
15 \text { patients }\end{array}$ & $4 \mathrm{mg} / 0.1 \mathrm{~mL}$ & $\begin{array}{l}\checkmark \text { (doses } \\
\text { tapered per } \\
\text { clinician } \\
\text { discretion) }\end{array}$ & $\checkmark$ & - & $\begin{array}{l}\text { Mean increase until first } \\
\text { month: } 0.6 \mathrm{I} \pm 0.33 \\
\text { (range, } 0 . \mathrm{I}-\mathrm{I} . \mathrm{I} \text { ). } 22.2 \% \text { had } \\
\text { further improvement after } \\
\text { I month. } 55.5 \% \text { maintained } \\
\text { improved VA until end of } \\
\text { follow-up }\end{array}$ \\
\hline $\begin{array}{l}\text { Sallam } \\
\text { et al" }\end{array}$ & $\begin{array}{l}41 \text { eyes of } \\
35 \text { patients }\end{array}$ & $\begin{array}{l}\text { At least two } \\
\text { injections of } \\
4 \mathrm{mg} / 0.1 \mathrm{~mL}\end{array}$ & $\begin{array}{l} \pm \text { (doses } \\
\text { tapered per } \\
\text { clinician } \\
\text { discretion) }\end{array}$ & \pm & - & $\begin{array}{l}\text { Each injection led to statistically } \\
\text { significant improvement in } \\
\text { BCVA }(P<0.0 \text { I). Efficacy of } \\
\text { repeated injections was similar }\end{array}$ \\
\hline
\end{tabular}

Notes: Data presented as mean \pm SD. “-”, data not available; \pm , treatment was or was not administered based on physician's discretion; $\checkmark$, treatment administered. Abbreviations: BCVA, best-corrected visual acuity; CS, corticosteroids; IVTA, intravitreal triamcinolone acetonide; ME, macular edema; VA, visual acuity.

of 4 weeks with the improvement being greater in younger patients as well as in those who had CME for a shorter period of time. About $54.5 \%$ of eyes were able to have their systemic medications reduced or stopped during the study duration with the mean follow-up time being 8 months. The main adverse ocular event observed was raised IOP; $43.1 \%$ of patients experienced a raise in IOP $>10 \mathrm{mmHg}$ but none required surgery, and $14.3 \%$ of patients with clear lens developed cataracts, whereas $11.8 \%$ of patients with preexisting cataracts experienced exacerbation during the mean follow-up period of 17.1 months. Eyes with a shorter mean follow-up period of 7 months did not show any lens changes. This is most possibly due to the likelihood of increased injections in the eyes with a longer follow-up period. Limitations of this study would be that it was a nonrandomized and uncontrolled study with variable follow-up periods.

In another retrospective case series of 49 eyes with Behçet's disease with a standardized follow-up period of at least 24 months, Park et al reported that $4 \mathrm{mg} / 0.1 \mathrm{~mL}$ of IVTA improved the BCVA in these eyes, which had been previously unresponsive or intolerant to systemic medications. ${ }^{9}$ After a median of 49 days, inflammation was under control as evident by the absence of vitreous haze $(\mathrm{VH})$ in $87 \%$ of eyes. However, $60 \%$ of these eyes relapsed before 12 months post-IVTA, and the mean time for uveitis recurrence was 210 days. With repeated injections, there was no statistically significant difference in the BCVA change in eyes 


\begin{tabular}{llllll}
\hline ME & Uveitis activity/ & Mean time to first \\
vitreous haze score & recurrence of uveitis & Uveitis & Reinjections & Others \\
\hline- & - & - & - & $12 \%$ & $54.5 \%$ eyes could \\
& & & & $\begin{array}{l}\text { reduce or stop } \\
\text { systemic medications }\end{array}$
\end{tabular}

$\begin{array}{lll}\begin{array}{l}\text { 85\% either } \\ \text { completely or }\end{array} & \begin{array}{l}6 \text { months: } 87 \% \text { patients } \\ \text { vitreous haze completely }\end{array} & \begin{array}{l}\text { Median } 210 \text { days } \\ \text { post-IVTA injection }\end{array} \\ \begin{array}{l}\text { partially resolved } \\ \text { after } 6 \text { months }\end{array} & \begin{array}{l}\text { resolved after median } \\ \text { period of } 49 \text { days }\end{array} & \text { (74-900 days) } \\ & \text { (range, } 6-152 \text { days) } & \\ & \text { postinjection }\end{array}$

$60 \%$ recurrence
before 12 months
postinjection

postinjection

postinjection

\begin{abstract}
Resolved after
I month
\end{abstract}

\section{Mean period of}

$25.4 \pm$ II. 3 days to

resolution of intraocular

inflammation
Mean 10 months

(range, 10-28 months)

\author{
$30.6 \%$ had repeated \\ injections in 24 months \\ (80\% one repeat, $20 \%$ \\ two repeats) \\ (no difference in \\ BCVA change with and \\ without repeated \\ injections)
}

$22 \%$ of eyes

0

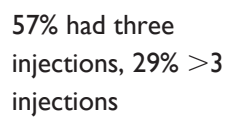

(range, I-13 months)

\author{
recurrence of $\mathrm{ME}$
}

$49 \%$ of patients

could reduce or stop systemic medications at 24 months
After second

injection: $76 \%$

improved

\section{Retinal vasculitis resolved after I month. Doses of systemic medications could be stopped or reduced}

$31 \%$ of patients could reduce or stop systemic medication with single versus multiple injections. Systemic medications were reduced or stopped in $49 \%$ of patients after 24 months. Side effects reported include cataract formation that was observed in $62 \%$ of phakic eyes after repeated injections as well as raised IOP in eyes with and without preexisting raised IOP. The effect of repeated IVTA injections on IOP was not evaluated in this study, as eyes with a significant raise in IOP following the initial injection did not receive a repeated injection.

Tuncer et al also performed a retrospective case series of 18 eyes with panuveitis secondary to Behçet's disease, which did not respond or were intolerant to systemic medications..$^{10}$ The authors reported that there was an increase in mean BCVA following the injection. Resolution of intraocular inflammation was also achieved after a mean of 25.4 days. Retinitis, vasculitis, as well as macular edema were resolved at the end of 1 month. However, recurrence of uveitis occurred at a period of 10-18 months. Similar to the previous studies, the dose for systemic corticosteroids was tapered down at 1-5 months, resulting in the improvement in cushingoid features. Ocular adverse events of cataracts and raised IOP were also observed.

Given that the studies have shown that repeated IVTA injections are likely to be required in the treatment of NIU due to its short duration of action, there have been concerns regarding the effects and safety of repeated IVTA injections. Sallam et al performed a retrospective consecutive case series of 41 uveitic eyes with CME which received 


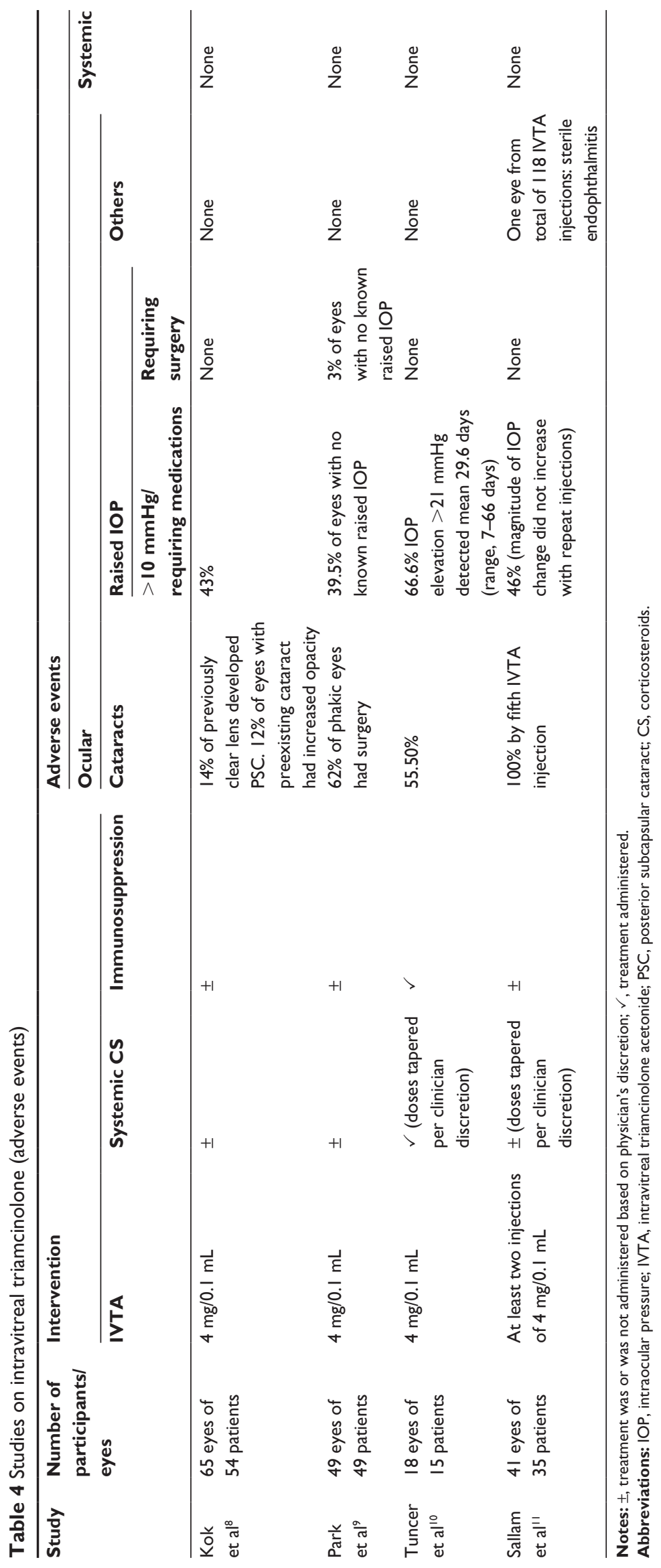




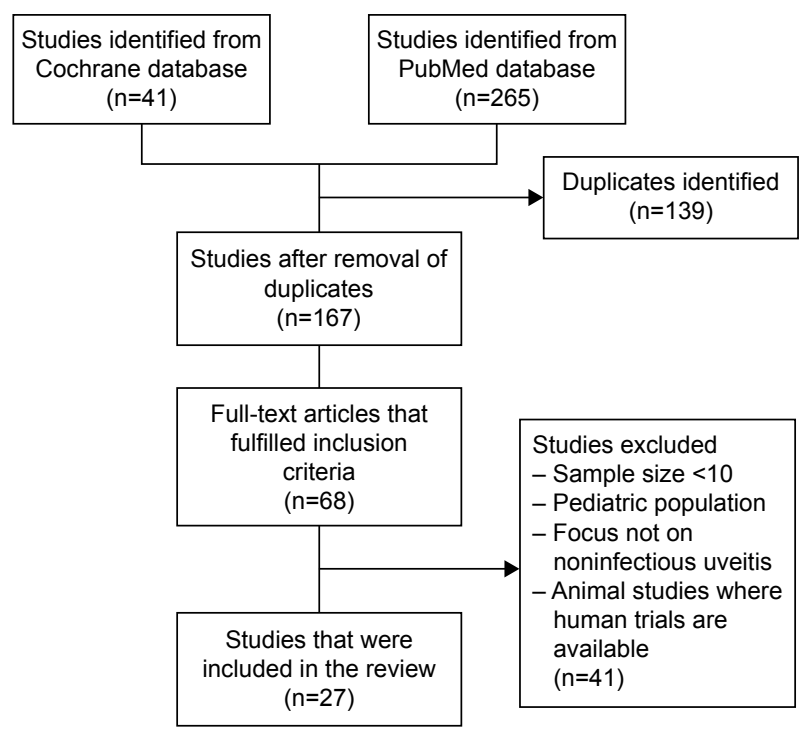

Figure I Literature review.

at least two IVTA injections. ${ }^{11}$ There was a statistically significant improvement in BCVA following each injection with no evidence of reducing efficacy with repeated injections. The majority of eyes had raised IOP, but there was no increase in the degree of change in IOP with each repeated injection. However, repeated IVTA injections were associated with increased cataract formation in all phakic patients (100\%). Importantly, patients were followed up for only 3 months after their last IVTA injections so the variable follow-up time may have affected the results, possibly resulting in an under-representation of ocular adverse events.

In summary, based on the literature review, it is found that IVTA can achieve improved visual acuity and inflammation control acutely but that repeated injections are needed to maintain the effects. It is also important to look out for the associated ocular adverse events such as cataract formation, which are more prominent with repeated injections, as well as increased IOP. Therefore, IVTA can be useful in NIU where patients are intolerant or nonresponsive to systemic medications and is also advisable in unilateral disease. Typically in bilateral patients, systemic immunosuppression is considered by most uveitis specialists.

\section{Corticosteroid implants}

The corticosteroid implants are able to maintain a sustained release of steroids over a prolonged period of time. This therefore decreases the need for repeated administration, such as in IVTA injections. Various implants have different properties, which are elaborated in the following subsections.

\section{$0.59 \mathrm{mg} \mathrm{FA}$}

The $0.59 \mathrm{mg}$ FAi (Retisert ${ }^{\circledR}$; Bausch \& Lomb Inc.) is an FDAapproved nonbiodegradable implant that is designed to maintain a sustained release of drug for $\sim 30$ months. ${ }^{12}$ Tables $5-8$ provide the summary of the studies regarding this implant.

The Multicenter Uveitis Steroid Treatment (MUST) trial is the largest randomized comparative trial to date regarding the efficacy, safety, and impact on quality of life of the FAi in comparison with systemic immunosuppression. ${ }^{13}$ About 479 uveitic eyes of 255 patients were observed over a period of 24 months. Both interventions resulted in improved BCVA with a larger absolute increase in mean BCVA in eyes treated with the FAi at all the time points. However, the difference was not statistically significant. Intraocular inflammation control was also achieved in most eyes by 9 months in each intervention. However, the implant achieved an increased frequency and rate of control compared with the systemic immunosuppression. The FAi was able to achieve resolution of macular edema in significantly more eyes than systemic treatment at 6 months, but this difference was not maintained at 24 months. Regarding adverse effects, patients treated with the implant were four times more likely to have an increased IOP, absolute IOP of $>35 \mathrm{mmHg}$ and increased need for medications and surgery to lower the IOP while $17 \%$ of eyes developed glaucoma. Friedman et al identified associations between raised IOP and black race, and uveitis activity and use of the implant. ${ }^{14}$ Cataracts developed in almost all the phakic eyes at the end of 24 months. As for systemic side effects, patients on systemic therapy had higher risk of a systemic infection requiring medications, but there was no significant increase in the risk of hospitalization. Vision-related quality of life was superior in patients with FAi at 6 months, but this advantage narrowed by the end of 24 months with minimal difference between the two.

In the 36-month follow-up to the original MUST trial, the FAi and systemic immunosuppression were similarly efficacious in improving the visual outcomes of the patients. ${ }^{1}$ However, there was no significant improvement of the mean BCVA at 54 months as compared to the baseline in either treatment arms. Lastly, macular edema was noted to improve significantly with the use of FAi in the first 6 months. However, with longer follow-up, the improvement in macular edema in both treatment arms was equal. The persistence of macular edema can potentially cause irreversible damage to the macula. The implant therapy may have an advantage in this area, as it is able to resolve macular edema to a greater extent initially. However, since there were no statistically 
Table 5 Studies on fluocinolone acetonide implants (demographics)

\begin{tabular}{|c|c|c|c|c|c|c|c|}
\hline \multirow[t]{2}{*}{ Study } & \multirow{2}{*}{$\begin{array}{l}\text { Period } \\
\text { of study }\end{array}$} & \multirow[t]{2}{*}{ Study design } & \multirow[t]{2}{*}{ Study duration } & \multirow{2}{*}{$\begin{array}{l}\text { Number of } \\
\text { participants/eyes }\end{array}$} & \multicolumn{3}{|l|}{ Demographics } \\
\hline & & & & & Age (years) & Sex (female) & Ethnicity \\
\hline $\begin{array}{l}\text { Multicenter } \\
\text { Uveitis Steroid }\end{array}$ & - & $\begin{array}{l}\text { Prospective, } \\
\text { randomized }\end{array}$ & 24 months & $\begin{array}{l}255 \text { (479 eyes } \\
\text { with uveitis) }\end{array}$ & $46.3 \pm 15.0$ & $75 \%$ & $\begin{array}{l}56 \% \text { white, } \\
13 \% \text { Hispanic }\end{array}$ \\
\hline $\begin{array}{l}\text { Treatment } \\
\text { (MUST) Trial }{ }^{1,13}\end{array}$ & & $\begin{array}{l}\text { comparative } \\
\text { effectiveness } \\
\text { trial cohort }\end{array}$ & 54 months & & & & $\begin{array}{l}\text { or Latino, } \\
26 \% \text { black, } \\
5 \% \text { others }\end{array}$ \\
\hline Callanan et $\mathrm{al}^{16}$ & $2000-2005$ & $\begin{array}{l}\text { Randomized, } \\
\text { historically } \\
\text { controlled trial }\end{array}$ & 3 years & $\begin{array}{l}\text { I } 10 \\
\text { Fellow eye }\end{array}$ & $\begin{array}{l}44.7 \pm 17.0 \\
\text { (range, } 7.0-84.0 \text { ) }\end{array}$ & $74 \%$ & $\begin{array}{l}68 \% \text { white, } \\
17 \% \text { African- } \\
\text { American, } \\
8 \% \text { Asians, } \\
4 \% \text { Hispanic, } \\
3 \% \text { others }\end{array}$ \\
\hline Pavesio et al $^{15}$ & 2002-2005 & $\begin{array}{l}\text { Randomized, } \\
\text { controlled, } \\
\text { phase } 2 b / 3 \text {, }\end{array}$ & 2 years & $\begin{array}{l}\text { I } 40 \text { eyes } \\
\text { (more severe } \\
\text { eye as study }\end{array}$ & $\begin{array}{l}40.36 \pm 14.363 \\
\text { (range, } 12.2-74.7 \text { ) }\end{array}$ & $48.50 \%$ & $\begin{array}{l}90.9 \% \text { white, } \\
6.1 \% \text { Hispanic, } \\
3 \% \text { others }\end{array}$ \\
\hline & & $\begin{array}{l}\text { open-label, } \\
\text { multicenter } \\
\text { superiority trial }\end{array}$ & & eye) & $\begin{array}{l}43.12 \pm 13.48 \\
\text { (range, } 17.5-70 \text { ) }\end{array}$ & $\begin{array}{l}67.6 \% \text { (the only } \\
\text { variable where } \\
\text { difference is } \\
\text { statistically } \\
\text { significant) }\end{array}$ & $\begin{array}{l}\text { 86.5\% white, } \\
\text { I.4\% black, } \\
5.4 \% \text { Hispanic, } \\
6.7 \% \text { others }\end{array}$ \\
\hline $\mathrm{Jaffe}^{18}$ & $\begin{array}{l}\text { March } 2004 \\
\text { to July } 2007\end{array}$ & $\begin{array}{l}\text { Prospective, } \\
\text { interventional } \\
\text { trial }\end{array}$ & $\begin{array}{l}\text { Mean follow-up post- } \\
\text { second implant: } \\
\text { I7 months } \\
\text { (range, 9-36 months) }\end{array}$ & $\begin{array}{l}17 \text { eyes of } \\
14 \text { patients }\end{array}$ & $\begin{array}{l}50 \text { (median: } 46.5 \text {, } \\
\text { range, 25-63) }\end{array}$ & $93 \%$ & $\begin{array}{l}72 \% \text { white, } \\
28 \% \text { black }\end{array}$ \\
\hline Bollinger et $\mathrm{al}^{17}$ & $\begin{array}{l}\text { June } 2001 \text { to } \\
\text { March } 2009\end{array}$ & $\begin{array}{l}\text { Retrospective } \\
\text { clinical case } \\
\text { series }\end{array}$ & $\begin{array}{l}\text { Median follow-up post- } \\
\text { implant: } 36 \text { months } \\
\text { (range, } 6-60 \text { months) }\end{array}$ & $\begin{array}{l}47 \text { eyes of } 35 \\
\text { patients }\end{array}$ & $\begin{array}{l}48.5 \pm 13.3 \\
\text { (range, 17-77) }\end{array}$ & $74 \%$ & $\begin{array}{l}94 \% \text { Caucasian, } \\
6 \% \text { African- } \\
\text { American }\end{array}$ \\
\hline
\end{tabular}

significant differences in BCVA, the advantage conferred is unlikely to be significant. Interestingly, only $10 \%$ of the uveitic eyes received two or more implants in this entire 54-month trial even though the estimated duration of action of FAi is $2.5-3$ years. Long-term studies are required to investigate whether this was due to the implant working for an extended duration or whether it is because the implant resulted in extended remission of uveitis.

In a randomized controlled phase $2 \mathrm{~b} / 3$ open-label multicenter superiority trial by Pavesio et $\mathrm{al}^{15}$ comparing the effects of FAi to the standard care (systemic steroids and/or immunosuppressive agents) with regard to time to first recurrence of uveitis, it was found that the uveitis recurrence number and the median time to recurrence were significantly lower with the use of FAi. However, there was no statistical difference in the BCVA improvement in both treatment arms at 24 months, consistent with the findings in the MUST trial. ${ }^{15}$ Nevertheless, the findings of CME seemed to be inconsistent with the MUST trial. In this study, there was a statistically significant higher proportion of subjects treated with FAi with the reduction in CME. This difference could be attributed to the difference in the method of measurement of macular edema; MUST trial used the optical coherence tomography, whereas the trial by Pavesio et $\mathrm{al}^{15}$ measured the area of CME using fluorescein angiography. As expected, a higher proportion of eyes with FAi developed cataracts and increased IOP at the end of the trial. There was also a higher incidence of hypotony in implanted eyes.

Callanan et al reported the results of a 3-year multicenter, randomized historically controlled trial of $0.59 \mathrm{mg}$ FAi in 110 patients. ${ }^{16}$ In this study, the FAi resulted in improved BCVA and significantly reduced uveitis recurrence. The use of the implant was associated with reduced dose of systemic medications. However, ocular adverse events, mainly increased IOP and cataract formation, were observed. There was also an increased incidence of hypotony in the implanted eyes as compared to the fellow eyes while retinal detachment occurred in $4 \%$ of the implanted eyes.

Bollinger et al evaluated the effect of FAi on IOP in a retrospective study of 47 eyes. ${ }^{17}$ They reported that glaucoma surgery was required for $45 \%$ of the patients over the 8 -year study period. Interestingly, there was no increase in the need for another IOP-lowering surgery following reimplantation in patients with previous IOP surgery secondary to raised IOP from the first implant. However, patients who experienced the need for glaucoma surgery after the first implant would be unlikely to choose reimplantation causing a bias in this 


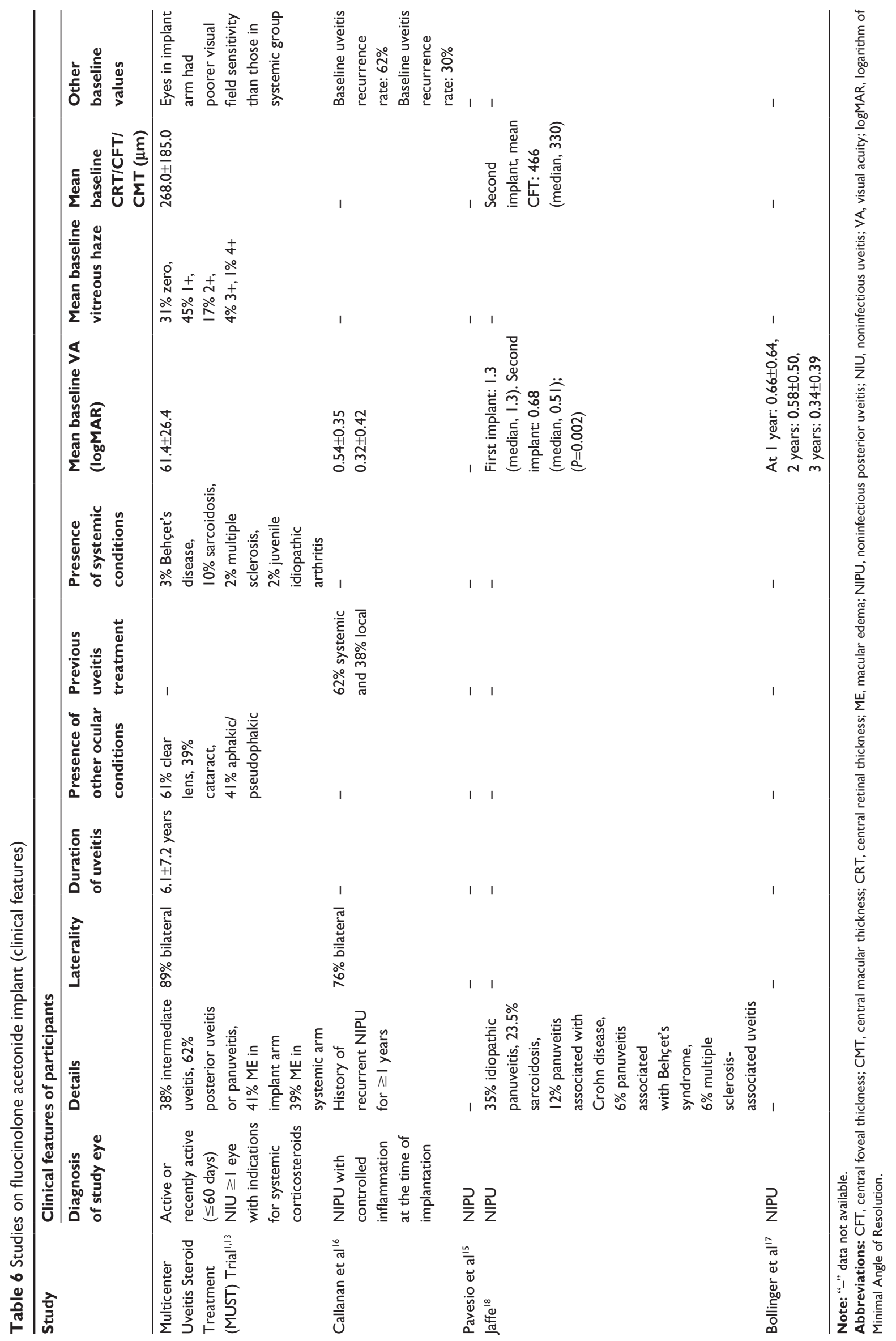


Table 7 Studies on fluocinolone acetonide implants (outcomes)

\begin{tabular}{|c|c|c|c|c|c|c|c|}
\hline \multirow[t]{2}{*}{ Study } & \multirow{2}{*}{\multicolumn{2}{|c|}{$\begin{array}{l}\text { Number of } \\
\text { participants/ } \\
\text { eyes }\end{array}$}} & \multicolumn{3}{|l|}{ Intervention } & \multirow{2}{*}{$\begin{array}{l}\text { Number excluding } \\
\text { those lost to } \\
\text { follow-up/ } \\
\text { dropout }\end{array}$} & \multirow{2}{*}{$\begin{array}{l}\text { Outcomes measured } \\
\text { BCVA }\end{array}$} \\
\hline & & & FAi & Systemic CS & Immunosuppression & & \\
\hline \multirow[t]{4}{*}{$\begin{array}{l}\text { Multicenter } \\
\text { Uveitis Steroid } \\
\text { Treatment } \\
\text { (MUST) Trial, }\end{array}$} & $\begin{array}{l}255 \text { (479 eyes } \\
\text { with uveitis) }\end{array}$ & 129 & $\checkmark$ & - & - & 122 & $\begin{array}{l}\text { Mean improvement at } \\
6 \text { months: } 5.9 \text { letters, } \\
12 \text { months: } 4.6 \text { letters, } \\
24 \text { months: } 6 \text { letters }\end{array}$ \\
\hline & & 126 & - & $\checkmark$ & $\ln 86 \%$ & 118 & $\begin{array}{l}6 \text { months: } 2.0 \text { letters, } \\
\text { I } 2 \text { months: } 3.3 \text { letters, } \\
24 \text { months: } 3.2 \text { letters. } \\
\text { No statistically significant } \\
\text { difference between the arms }\end{array}$ \\
\hline & & 129 & $\checkmark$ & - & - & 110 & No statistically significant \\
\hline & & 126 & - & $\checkmark$ & $\ln 86 \%$ & 103 & $\begin{array}{l}\text { differences between arms. } \\
\text { Mean improvement } \\
54 \text { months: } 2.4 \text { letters in } \\
\text { implant arm vs } 3.1 \text { letters in } \\
\text { systemic arm }\end{array}$ \\
\hline \multirow[t]{2}{*}{ Callanan et $\mathrm{al}^{16}$} & 110 & & $\checkmark$ & \pm & \pm & 98 & $\begin{array}{l}\text { I year: } 0.56 \pm 0.44(P=0.75) \\
2 \text { years: } 0.40 \pm 0.37(P<0.0 \mathrm{I}) \\
3 \text { years: } 0.48 \pm 0.4 \mathrm{I} \quad(P=0.18)\end{array}$ \\
\hline & Fellow eye & & - & - & - & - & $\begin{array}{l}\text { I year: } 0.39 \pm 0.49(P<0.0 \mathrm{I}) \\
2 \text { years: } 0.39 \pm 0.49(P<0.0 \mathrm{I}) \\
3 \text { years: } 0.42 \pm 0.5 \mathrm{I}(P<0.0 \mathrm{I})\end{array}$ \\
\hline Pavesio et al ${ }^{15}$ & $\begin{array}{l}\text { I } 40 \text { (more } \\
\text { severe eye as } \\
\text { study eye) }\end{array}$ & 66 & Yes & $\begin{array}{l}\checkmark \\
\text { (monotherapy } \\
\mathrm{CS} \geq 0.2 \mathrm{mg} / \mathrm{kg} \\
\text { daily) }\end{array}$ & \pm & 71 & $\begin{array}{l}\text { Mean VA in systemic group } \\
\text { consistent, implant group } \\
\text { deteriorated at } 0,15 \text {, } \\
18 \text { months. At } 2 \text { years: VA } \\
\text { stabilized in } 71.2 \% \text { implanted } \\
\text { arm and } 73 \% \text { systemic } \\
\text { arm; } 17.2 \% \text { implanted arm } \\
\text { vs } 14.3 \% \text { systemic arm } \\
\text { improved } \\
\text { by } \geq 3 \text { lines }(P=0.66)\end{array}$ \\
\hline Jaffe $^{18}$ & $\begin{array}{l}17 \text { eyes of } \\
14 \text { patients }\end{array}$ & & $\checkmark$ & - & - & - & $\begin{array}{l}52 \text { weeks post-second } \\
\text { implant mean } B C V A \text { : } \\
0.60 \text { (median, } 0.35) \\
(P=0.04 \text { compared with } \\
\text { the } V A \text { at the time of first } \\
\text { implant) }\end{array}$ \\
\hline Bollinger et $\mathrm{al}^{17}$ & $\begin{array}{l}47 \text { eyes of } \\
35 \text { patients }\end{array}$ & & $\begin{array}{l}\checkmark(25.5 \% \\
\text { had multiple } \\
\text { implants })\end{array}$ & - & - & - & $\begin{array}{l}\text { I year: } 0.39 \pm 0.53(P=0.03) \\
2 \text { years: } 0.28 \pm 0.36(P=0.01) \\
3 \text { years: } 0.34 \pm 0.39(P=0.04)\end{array}$ \\
\hline
\end{tabular}

Notes: “-”, data not available; \pm , treatment was or was not administered based on physician's discretion; $\checkmark$, treatment administered.

Abbreviations: BCVA, best-corrected visual acuity; CFT, central foveal thickness; CS, corticosteroids; CME, cystoid macular edema; CMT, central macular thickness; CRT, central retinal thickness; FAi, fluocinolone acetonide implant; MD, mean deviation; ME, macular edema; VA, visual acuity. 


\begin{tabular}{|c|c|c|c|c|c|c|c|}
\hline Visual field MD & $\begin{array}{l}\text { Mean CRT/ } \\
\text { CMT/CFT } \\
(\mu \mathrm{m})\end{array}$ & ME & $\begin{array}{l}\text { Uveitis } \\
\text { activityl } \\
\text { vitreous haze } \\
\text { score }\end{array}$ & $\begin{array}{l}\text { Mean time to } \\
\text { first recurrence } \\
\text { of uveitis }\end{array}$ & $\begin{array}{l}\text { Uveitis } \\
\text { recurrence } \\
\text { rate }\end{array}$ & Reimplantation & Others \\
\hline $\begin{array}{l}\text { Remained similar } \\
\text { to baseline } \\
\text { throughout } \\
48 \text { months of } \\
\text { follow-up in both } \\
\text { arms }\end{array}$ & - & $\begin{array}{l}6 \text { months: } 20 \% \\
\text { in implant vs } \\
34 \% \text { in systemic } \\
\text { arm, }(P<0.00 \text { I } \\
\text { difference in } \\
\text { change statistically } \\
\text { significant between } \\
\text { groups); } 24 \text { months: } \\
22 \% \text { in implant vs } \\
30 \% \text { in systemic } \\
\text { arm ( } P=0.07 \text { I) } \\
36 \text { months: } \\
\text { improved in } \\
\text { systemic arm, } \\
\text { stabilized in } \\
\text { implant arm; } \\
48 \text { months: } ~ 20 \% \\
\text { in each arm }\end{array}$ & $\begin{array}{l}\text { Implant arm } \\
\text { better in } \\
\text { inflammation } \\
\text { control at all } \\
\text { time points } \\
\text { assessed } \\
(P<0.016) \text {, } \\
\text { but systemic } \\
\text { arm also had } \\
\text { substantial } \\
\text { improvement }\end{array}$ & - & - & $\begin{array}{l}\text { At } 54 \text { months: } \\
87 \% \text { of eyes } \geq 1 \\
\text { implant, } 8 \% \text { had } \\
\text { two implants, } \\
2 \% \text { had } \\
\text { three implants }\end{array}$ & - \\
\hline $\begin{array}{l}\text { Reduction in } M D \text { at } \\
3 \text { years: }-1.42 \mathrm{~dB} \\
\text { ( } P=0.05 \text { compared } \\
\text { to baseline }) \\
\text { Reduction at } \\
3 \text { years: }-1.05 \mathrm{~dB} \\
(P=0.05 \text { compared } \\
\text { to baseline) }\end{array}$ & - & $\begin{array}{l}\text { Reduction in CME } \\
\text { I year: } 86 \% \text { eyes; } \\
3 \text { years: } 73 \% \text { eyes } \\
\text { Reduction in CME } \\
\text { I year: } 28 \% \text { eyes; } \\
3 \text { years: } 28 \% \text { eyes }\end{array}$ & 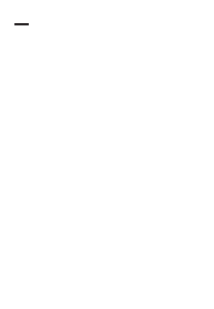 & $\begin{array}{l}\text { No recurrences } \\
\text { until I,000 days } \\
\text { after implantation }\end{array}$ & $\begin{array}{l}\text { I year: } 4 \%, \\
2 \text { years: } 10 \%, \\
3 \text { years: } 20 \% \\
(P=0.0 \text { I }) \\
\text { I year: } 44 \%, \\
2 \text { years: } 52 \%, \\
3 \text { years: } 59 \% \\
(P<0.0 \text { I })\end{array}$ & - & - \\
\hline $\begin{array}{l}\text { No statistically } \\
\text { significant } \\
\text { difference between } \\
\text { groups. Mean } \\
\text { change from }\end{array}$ & - & $\begin{array}{l}\text { Higher rate of } \\
\text { CME improvement. } \\
\text { Reduction in CME } \\
2 \text { years: } 86.5 \% \text { eyes }\end{array}$ & $\begin{array}{l}\text { Mean vitreous } \\
\text { haze severity of } \\
\text { implanted arm } \\
<\text { systemic arm } \\
(P<0.0 \text { I })\end{array}$ & $6.4 \pm 7.0$ months & $18.20 \%$ & - & - \\
\hline $\begin{array}{l}\text { baseline at } \\
24 \text { months }<1 \mathrm{~dB}\end{array}$ & & $\begin{array}{l}\text { Reduction in CME } \\
\text { at } 2 \text { years: } 74.4 \% \\
\text { eyes }\end{array}$ & & $\begin{array}{l}7.1 \pm 7.2 \text { months } \\
\text { (between } \\
\text { treatment arms: } \\
P=0.07 \text { ) }\end{array}$ & $\begin{array}{l}63.5 \% \\
\text { (between } \\
\text { treatment } \\
\text { arms: } P=0.01 \text { ) }\end{array}$ & - & - \\
\hline- & $\begin{array}{l}4 \text { weeks post- } \\
\text { second implant: } \\
293 \text { (median, } \\
200)(P=0.0004) \text {, } \\
52 \text { weeks post- } \\
\text { second implant: } \\
\text { I54 (median, } \\
\text { I59) }(P=0.02)\end{array}$ & - & - & $\begin{array}{l}\text { Mean time from } \\
\text { first implant } \\
\text { to first uveitis } \\
\text { recurrence: } \\
38 \text { months }\end{array}$ & $\begin{array}{l}\text { No } \\
\text { recurrences } \\
\text { after second } \\
\text { implant at } \\
52 \text { weeks }\end{array}$ & $\begin{array}{l}\text { Mean time of first } \\
\text { recurrence of } \\
\text { inflammation to } \\
\text { reimplantation: } \\
8 \text { months } \\
\text { (median, } \\
5 \text { months; range, } \\
2-26 \text { months) }\end{array}$ & $\begin{array}{l}\text { Adjunctive } \\
\text { CS use } \\
\text { decreased } \\
\text { significantly }\end{array}$ \\
\hline- & - & - & - & - & - & - & - \\
\hline
\end{tabular}




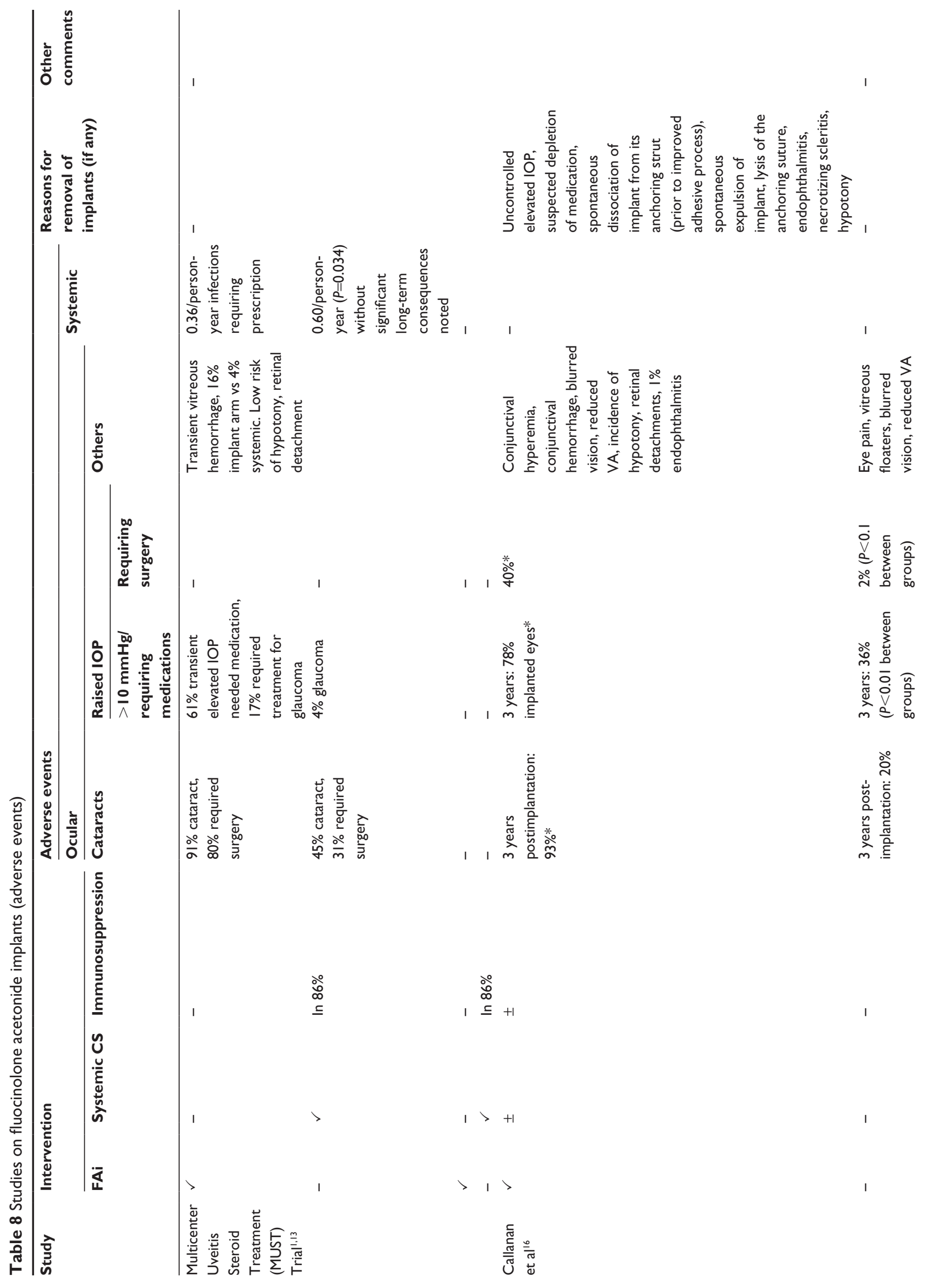



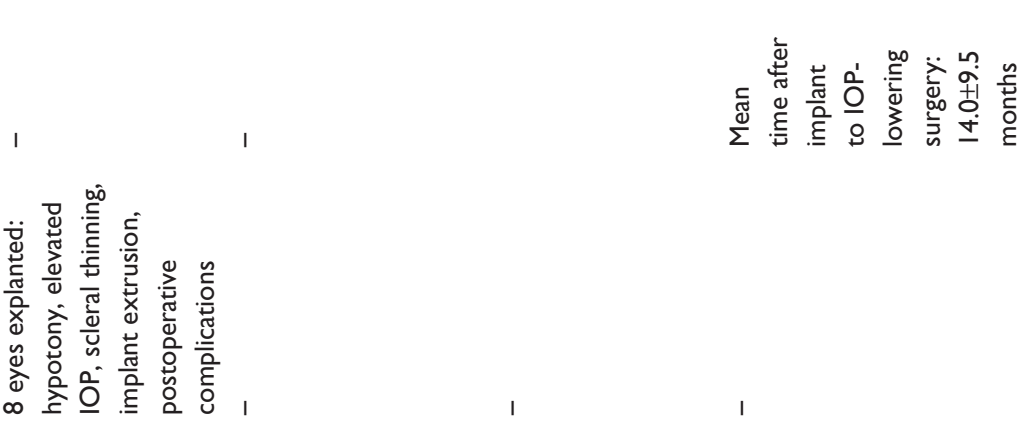

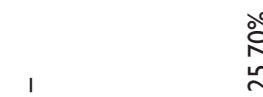

$\stackrel{\circ}{\stackrel{0}{\leftrightarrow}}$

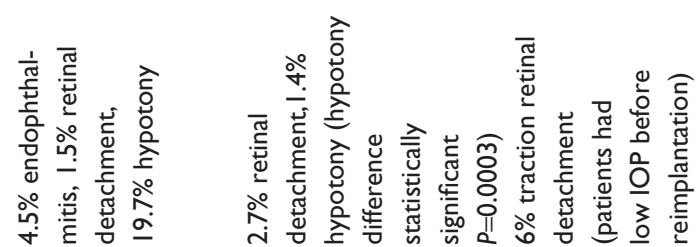

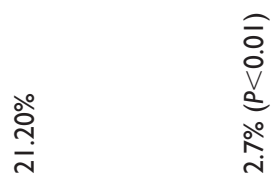
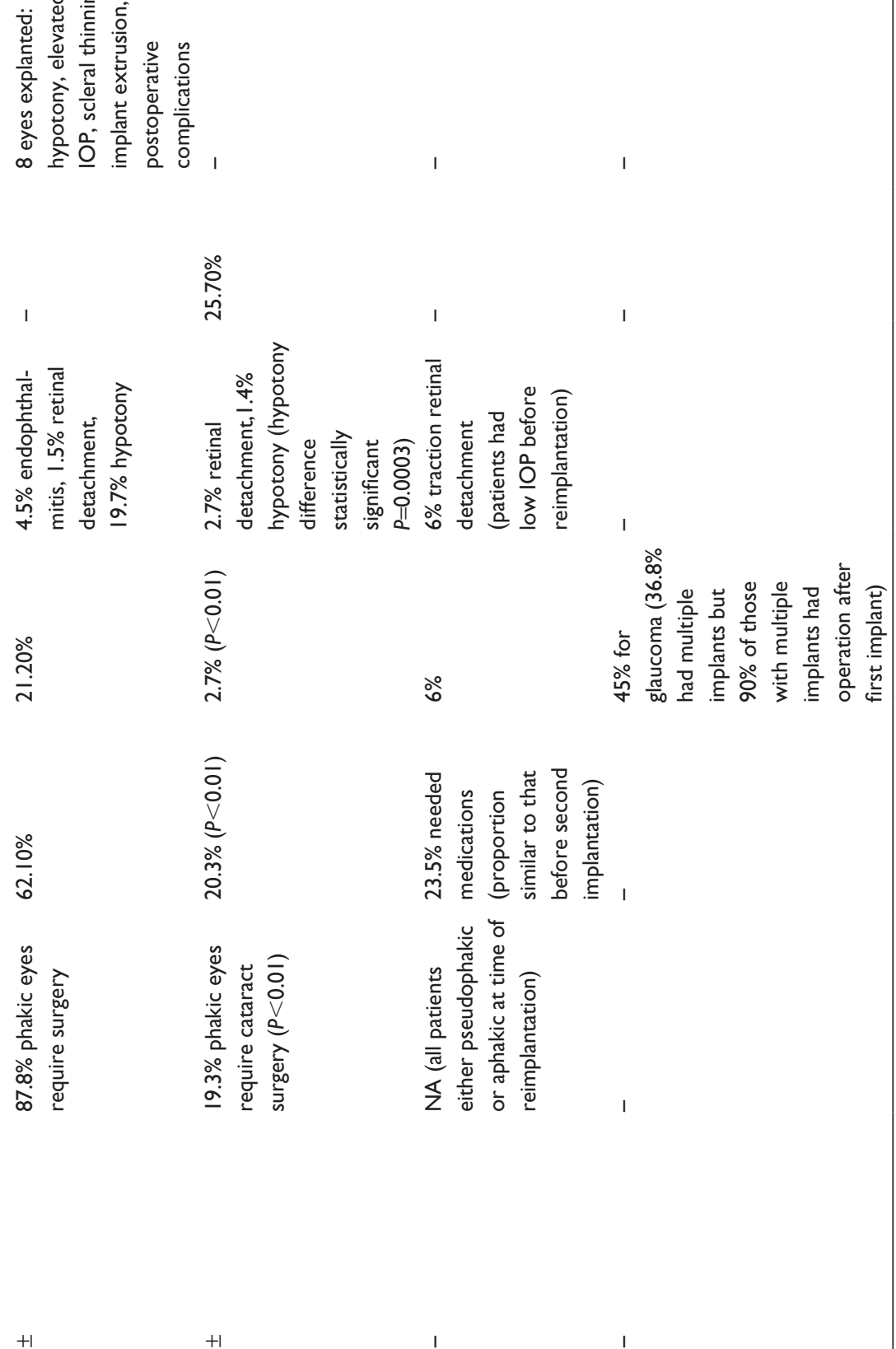

$+$

$+1$

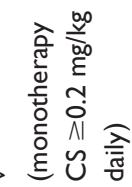

$+1$

这

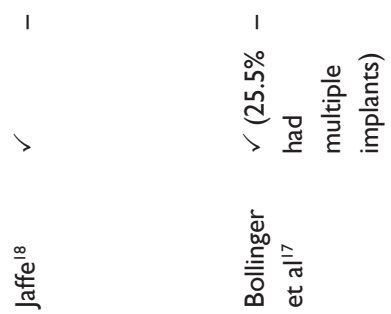

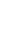

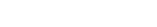

ถ̊ำ

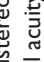


observation. Furthermore, this was a retrospective study, which has inherent biases.

$\mathrm{Jaffe}^{18}$ performed a prospective interventional trial, as a continuum from the study by Callanan et al. ${ }^{16}$ Reimplantation of FAi was effective in sustaining the control of intraocular inflammation and stabilization of BCVA of the eye in 17 eyes of 14 patients. None of the eyes developed recurrence of inflammation in the 52-week period after reimplantation. However, one patient developed recurrent iridocyclitis 34 months after the second implant and was treated with prednisolone and replacement of the second implant. It was possible to place the second implant at the original implant site, and no intraoperative complications were observed with the reimplantation. With regard to ocular adverse events as a result of the second implantation, the proportion of patients requiring IOP-lowering medications was similar to the proportion before reimplantation. Two patients had IOP $>35 \mathrm{mmHg}$, but this was postulated to be due to noncompliance with IOP lowering medications. The risk of cataract formation after repeated implantations could not be evaluated, as all patients were either pseudophakic or aphakic at the time of reimplantation.

From the results of the studies, it is found that FAi does not seem to confer a substantial advantage in the improvement of BCVA but is advantageous in intraocular inflammation control. The use of the implant also allows for reduction in systemic medications. However, in patients with bilateral disease, the cost of bilateral FAi was greater than that of systemic corticosteroids. ${ }^{19}$ Therefore, given that the FAi has minimal advantage in visual outcomes and avoidance of systemic side effects from systemic corticosteroids, with additional ocular adverse events such as raised IOP and cataract development coupled with increased cost for bilateral disease, alternate forms of treatment such as newer implants or systemic agents may be preferable as a first-line treatment in patients with bilateral NIU.

\section{Dexamethasone implant}

The $0.7 \mathrm{mg}$ dexamethasone implant (Ozurdex ${ }^{\circledR}$; Allergan Inc) is an FDA-approved biodegradable dexamethasone implant. The implantation of the dexamethasone implant can be performed as an outpatient procedure, and it maintains sustained release for up to 6 months. ${ }^{2}$ Tables 9-12 provide the summary of studies regarding dexamethasone implant.

The HURON trial, a multicenter randomized controlled trial reported by Lowder et al evaluated the effect of $0.7 \mathrm{mg}$ dexamethasone implant in 77 eyes over a period of 26 weeks in improving $\mathrm{VH}$ as the primary outcome. ${ }^{20}$ There was a statistically significant improvement in BCVA in eyes implanted with $0.7 \mathrm{mg}$ dexamethasone compared with the controls. The implant also proved its ability to control ocular inflammation as $47 \%$ of eyes achieved a $\mathrm{VH}$ score of 0 by the end of 8 weeks. A significant decrease in central macular thickness (CMT) from baseline was observed. Improvement in $\mathrm{VH}$ and BCVA were noted up to 26 weeks; however, $22 \%$ of patients required rescue medications. Of note, there was no statistically significant difference in the proportion of patients requiring rescue medications as compared to the control. As for adverse events, $\leq 23 \%$ patients with $0.7 \mathrm{mg}$ dexamethasone implant required IOP-lowering medications. Cataract was observed in $15 \%$ of the phakic eyes treated with the implant compared with $7 \%$ of eyes in the control group, and only one eye required surgery. However, this difference was not statistically significant. Limitations of this study include a shorter follow-up period (6 months), and adverse effects such as cataract formation would not have been detected fully. Furthermore, the trial had no information regarding the efficacy of repeated implantation of $0.7 \mathrm{mg}$ dexamethasone.

In a retrospective case series of 18 eyes, Khurana and Porco investigated the effect of $0.7 \mathrm{~g}$ dexamethasone implant on persistent uveitic CME. ${ }^{21}$ BCVA improved in this retrospective study with a complete resolution of CME at 1 month. However, CME recurred at a median time interval of 201 days. Adverse events noted in the study included an increase in IOP in $11 \%$ of eyes $(>25 \mathrm{mmHg})$. However, IOP was controlled in all patients with medical therapy. The results from this study are largely consistent with another retrospective study by Lam et al, which studied 23 eyes with uveitic macular edema. ${ }^{22}$ BCVA also improved with the reduction of the central retinal thickness (CRT). About $22 \%$ of uveitic eyes had an increase in IOP of $>10 \mathrm{mmHg}$, but were all under control with medications. However, the incidence of cataract surgery seems to be higher in this study at $43.6 \%$ of phakic eyes. This could be due to the fact that there was variable follow-up time and lack of baseline lens opacity and that most patients have had other types of treatment such as IVTA administered prior to this trial. However, there is still an inconsistency as the study by Khurana and Porco $^{21}$ also consisted of patients with previous treatment using IVTA and other drugs; therefore, the difference could be because both the studies did not manage to measure the lens opacity at baseline, since they were retrospective studies.

A retrospective study by Tomkins-Netzer et al looked into the clinical question of the effect of repeated dexamethasone 


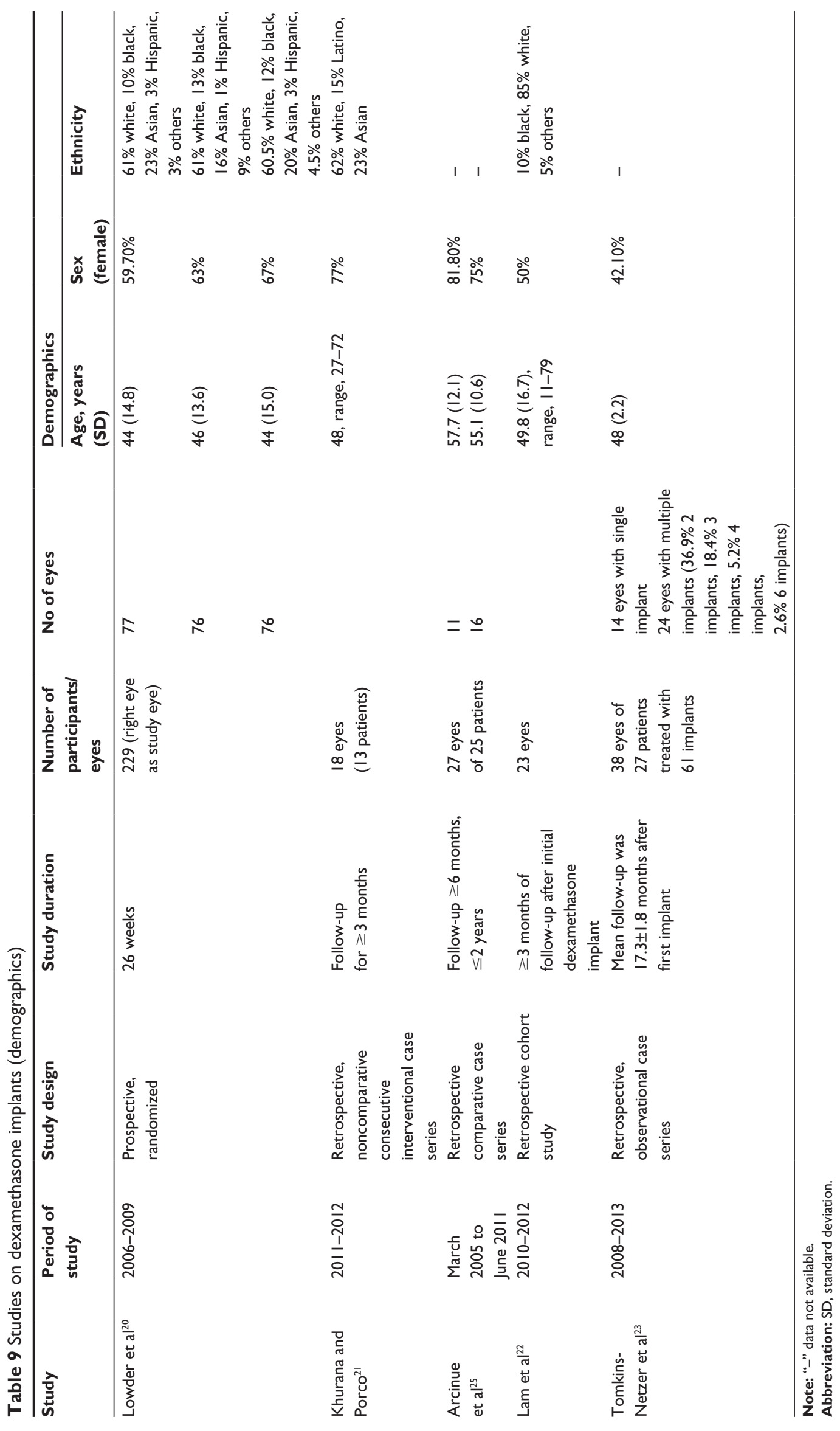


Table 10 Studies on dexamethasone implants (clinical features)

\begin{tabular}{|c|c|c|c|c|}
\hline \multirow[t]{2}{*}{$\overline{\text { Study }}$} & \multicolumn{4}{|c|}{ Clinical features of participants } \\
\hline & $\begin{array}{l}\text { Diagnosis } \\
\text { of study } \\
\text { eye }\end{array}$ & Details & $\begin{array}{l}\text { Duration of uveitis } \\
\text { (SD) }\end{array}$ & $\begin{array}{l}\text { Presence of other ocular } \\
\text { conditions }\end{array}$ \\
\hline \multirow[t]{3}{*}{ Lowder et al ${ }^{20}$} & NIU & $\begin{array}{l}81 \% \text { intermediate, } \\
19 \% \text { posterior }\end{array}$ & $50.5(54.2)$ & $\begin{array}{l}81 \% \text { phakic, } 32 \% \text { cataract in } \\
\text { phakic lens }\end{array}$ \\
\hline & & & $43.9(48.9)$ & $\begin{array}{l}67 \% \text { phakic, } 63 \% \text { cataract in } \\
\text { phakic lens }\end{array}$ \\
\hline & & & $61.2(62.5)$ & $\begin{array}{l}72 \% \text { phakic, } 49 \% \text { cataract in } \\
\text { phakic lens }\end{array}$ \\
\hline $\begin{array}{l}\text { Khurana and } \\
\text { Porco }{ }^{21}\end{array}$ & $\begin{array}{l}\text { Persistent, } \\
\text { noninfectious } \\
\text { uveitic CME }\end{array}$ & $\begin{array}{l}39 \% \text { intermediate uveitis, } \\
22 \% \text { birdshot chorioretinitis, } \\
22 \% \text { sarcoidosis, and } \\
17 \% \text { others }\end{array}$ & $\begin{array}{l}\text { Median duration of } \\
\text { CME: } 16.5 \text { months } \\
\text { (range, } 4-39 \text { months) }\end{array}$ & $55 \%$ phakic \\
\hline \multirow[t]{2}{*}{ Arcinue et $\mathrm{al}^{25}$} & NIU & $0.59 \mathrm{mg} \mathrm{FAi}$ & - & $36.4 \%$ glaucoma \\
\hline & & $0.7 \mathrm{mg} F A i$ panuveitis & - & $56.3 \%$ glaucoma \\
\hline Lam et $\mathrm{al}^{22}$ & NIU with ME & - & $\begin{array}{l}<3 \text { months of ME: } 8.7 \%, \\
\geq 3-12 \text { months: } 30.4 \%, \\
\geq 12 \text { months: } 56.5 \%, \\
\text { unknown duration: } 4.3 \%\end{array}$ & $\begin{array}{l}\text { 17.4\% previous glaucoma surgery, } \\
47.8 \% \text { phakic, } 52.2 \% \text { pseudophakic }\end{array}$ \\
\hline $\begin{array}{l}\text { Tomkins-Netzer } \\
\text { et } \mathrm{al}^{23}\end{array}$ & NIU & $\begin{array}{l}23.69 \% \text { intermediate uveitis, } \\
76.31 \% \text { posterior uveitis plus } \\
\text { panuveitis, } 92.1 \% \text { CME, } 7.81 \% \\
\text { vitritis }\end{array}$ & Mean: $90.95 \pm$ I I.06 months & $55.26 \%$ phakic \\
\hline
\end{tabular}

Note: “-” data not available.

Abbreviations: CFT, central foveal thickness; CME, cystoid macular edema; CMT, central macular thickness; CRT, central retinal thickness; FAi, fluconinolone acetnoide implant; IOP, intraocular pressure; IVTA, intravitreal triamcinolone acetonide; logMAR, logarithm of Minimal Angle of Resolution; ME, macular edema; NIU, noninfectious uveitis; VA, visual acuity.

implants in the treatment of NIU in 38 eyes. ${ }^{23}$ The study reported that BCVA and CRT improved within 1-2 months after each implantation, and the effect was sustained for about 6 months. Repeated implantations showed similar efficacy and resulted in a cumulative effect that allowed for continuous improvement of BCVA and CRT of the eyes. Following the first implantation of dexamethasone, systemic or local immunosuppressive therapy could be reduced or terminated in $87 \%$ of eyes. Cataract development was minimal in this study, in only $5 \%$ of phakic eyes after the first and third implantations. There were seven cases of increased IOP of $>25 \mathrm{mmHg}$, three eyes after the first implantation and four eyes after the second. However, all were treated with medications with none requiring surgery. There was one case of migration of the implant into the anterior chamber.

A retrospective study of 20 eyes with intraocular inflammation, mostly secondary to NIU, implanted with bilateral dexamethasone implants by Ryder et al revealed that the bilateral implants appeared to be well-tolerated with no patients developing cataracts during their follow-up period. ${ }^{24}$
However, similar to patients with unilateral dexamethasone implants, there was an elevation of IOP with $18.2 \%$ of eyes, requiring medications. Large-scale studies are required to establish the safety profile of bilateral dexamethasone implants.

In summary, based on the literature review, the studies showed that the dexamethasone implant improves BCVA and CMT as well as CME with a lower incidence of cataract formation and raised IOP compared with the FAi among patients with NIU. Repeated implants seem to work with the same efficacy with minimal additional side effects, and bilateral implants appear to be well-tolerated as well. However, common limitations in these trials except the HURON trial were that they were all retrospective studies with relatively smaller sample size. The HURON trial did not examine the long-term effects of the dexamethasone implant as well as the effect of repeated implantations.

Since both the FAi and dexamethasone implants are long-acting and avoid the systemic side effects of oral corticosteroids, Arcinue et al performed a retrospective study to compare the safety and efficacy of the two, which may help to 


\begin{tabular}{|c|c|c|c|c|c|}
\hline $\begin{array}{l}\text { Previous uveitis } \\
\text { treatment/at study } \\
\text { entry }\end{array}$ & $\begin{array}{l}\text { Presence of } \\
\text { systemic conditions }\end{array}$ & $\begin{array}{l}\text { Mean baseline } \\
\text { VA (logMAR) }\end{array}$ & $\begin{array}{l}\text { Mean baseline } \\
\text { vitreous haze }\end{array}$ & $\begin{array}{l}\text { Mean baseline CRT/ } \\
\text { CFT/CMT }(\mu \mathrm{m})\end{array}$ & $\begin{array}{l}\text { Other baseline } \\
\text { values }\end{array}$ \\
\hline $\begin{array}{l}26 \% \text { on systemic } \\
\text { medication }\end{array}$ & - & $58 \pm 15.2$ & $2.06 \pm 0.55$ & CMT: $344.0 \pm 141.6$ & - \\
\hline $\begin{array}{l}29 \% \text { on systemic } \\
\text { medication }\end{array}$ & - & $57 \pm 17.2$ & $2.12 \pm 0.50$ & CMT: $338.9 \pm 162.4$ & - \\
\hline $\begin{array}{l}24 \% \text { on systemic } \\
\text { medication }\end{array}$ & - & $63 \pm 15.2$ & $2.0 I \pm 0.54$ & CMT: $324.6 \pm 145.5$ & - \\
\hline $\begin{array}{l}78 \% \text { eyes } \geq I \text { therapy for } \\
\text { uveitic CME. } 72 \% \text { not on } \\
\text { any therapy. } 28 \% \text { eyes on } \\
\text { systemic medication }\end{array}$ & - & $\begin{array}{l}50 \% 10 / 30-10 / 50 \\
39 \% 10 / 60-10 / 80 \\
11 \% 10 / 100-10 / 150\end{array}$ & $\begin{array}{l}56 \% \text { score of } 0, \\
33 \% \text { score of } I, \\
I I \% \text { score of } 2\end{array}$ & $\begin{array}{l}\text { Median CRT: } 453 \\
\text { (range, 3I4-778) }\end{array}$ & - \\
\hline $\begin{array}{l}18 \% \text { on systemic } \\
\text { medications }\end{array}$ & - & - & - & CRT: $379.2 \pm 124.3$ & - \\
\hline $\begin{array}{l}56 \% \text { on systemic } \\
\text { medications }\end{array}$ & - & - & - & CRT: $340.3 \pm|4| .0$ & - \\
\hline $\begin{array}{l}\text { IVTA: } 65.2 \% \text {, sub-Tenon's } \\
\text { triamcinolone acetonide: } \\
43.5 \% \text {, some on systemic } \\
\text { medications }\end{array}$ & $26 \%$ hypertension & $0.7 \mathrm{I} \pm 0.07$ & - & $\begin{array}{l}\text { CRT: } 5 I 7.2 \pm 40.3 \\
\text { (range, 285-872) }\end{array}$ & - \\
\hline $\begin{array}{l}74 \% \text { on systemic } \\
\text { prednisolone, } 70 \% \text { on } \\
\text { second-line agents }\end{array}$ & - & $0.47 \pm 0.05$ & $\begin{array}{l}57.89 \% \text { score } \\
0,41.22 \% \\
\text { score }+0.5 \\
\text { to }+2\end{array}$ & CRT: $453.29 \pm 33.57$ & $\begin{array}{l}\text { Mean IOP: } \\
13.87(0.43) \mathrm{mmHg} \text {, } \\
7 \text { steroid } \\
\text { responders }\end{array}$ \\
\hline
\end{tabular}

arrive at a conclusion. ${ }^{25}$ The main outcome evaluated in this study was the recurrence rate of uveitis following implantation. The FAi and dexamethasone implants showed relatively similar efficacy since there were no statistically significant differences with regard to their effect on BCVA and inflammation control. Recurrence rates were higher in the FAi group, but the difference was not statistically significant. The investigator postulated that this could be due to the increased severity of uveitis in the eyes implanted with FAi. Furthermore, it was more likely for a patient to have had a reimplantation of the dexamethasone implant given its designated functioning duration of 6 months, therefore decreasing the recurrence rate. Expanding on that point, as the duration of action of the Ozurdex is significantly shorter, it was five times more likely for eyes with dexamethasone implants to require a second implant. Expectedly, FA-implanted eyes had a statistically higher rate of requiring IOP-lowering medications or surgeries, and 4.7-fold increased risk in cataract formation was noted with FAis. Similar to other trials, this study had several limitations including retrospective nature, small sample size, and variable follow-up period. Therefore, the choice between the two depends on the patient's individual circumstances.

\section{$0.019 \mathrm{mg} F \mathrm{Fi}$}

The 0.019 mg FAi (ILUVIEN ${ }^{\circledR}$; Alimera Sciences Limited) was recently FDA-approved for the treatment of diabetic macular edema. The effect lasts for up to 36 months. ${ }^{26}$ With its lower dosage than $0.59 \mathrm{mg}$ FAi, the corticosteroid side effects are thought to be reduced with this implant. The phase III clinical trial for FAi in NIU is currently ongoing. ${ }^{27}$

\section{Intravitreal antivascular endothelial growth factor: bevacizumab and ranibizumab}

The vascular endothelial growth factor (VEGF) has been found to be a vital component in the pathogenesis of CME and CNV. Inhibition of VEGF with the anti-VEGF is therefore able to impair the angiogenic effects. It has been widely used in the treatment of CNV secondary to age-related macular degeneration and has also been used in other ocular 
Table I I Studies on dexamethasone implants (outcomes)

\begin{tabular}{|c|c|c|c|c|c|c|c|}
\hline \multirow[t]{2}{*}{ Study } & \multirow{2}{*}{\multicolumn{2}{|c|}{$\begin{array}{l}\text { Number of participants/ } \\
\text { eyes }\end{array}$}} & \multicolumn{3}{|c|}{ Intervention } & \multirow{2}{*}{$\begin{array}{l}\text { Numbers } \\
\text { excluding } \\
\text { those lost } \\
\text { to follow-up/ } \\
\text { dropout }\end{array}$} & \multirow{2}{*}{$\begin{array}{l}\text { Outcomes measured } \\
\text { BCVA }\end{array}$} \\
\hline & & & $\begin{array}{l}\text { DEX } \\
\text { implant }\end{array}$ & $\begin{array}{l}\text { Systemic } \\
\text { CS (unless } \\
\text { otherwise } \\
\text { stated) }\end{array}$ & $\begin{array}{l}\text { Immuno- } \\
\text { suppression }\end{array}$ & & \\
\hline \multirow[t]{3}{*}{ Lowder et $\mathrm{al}^{20}$} & $\begin{array}{l}229 \text { (right } \\
\text { eye as }\end{array}$ & 77 & $0.7 \mathrm{mg}$ & \pm & \pm & 73 & $\begin{array}{l}\text { Mean improvement in } \\
\text { BCVA: Dex }>\text { sham }\end{array}$ \\
\hline & study eye) & 76 & $0.35 \mathrm{mg}$ & \pm & \pm & 73 & $\begin{array}{l}\text { groups. Statistically } \\
\text { significant at all time } \\
\text { points for } 0.7 \mathrm{mg} \text {. Dex } \\
\text { implant } 2-6 \text { times more } \\
\text { eyes with } 15 \text {-letter } \\
\text { improvement from } \\
\text { baseline compared with } \\
\text { sham group }\end{array}$ \\
\hline & & 76 & $\begin{array}{l}\text { Sham } \\
\text { procedure }\end{array}$ & \pm & \pm & 71 & - \\
\hline Khurana and Porco ${ }^{21}$ & $\begin{array}{l}18 \text { eyes of } \\
13 \text { patients }\end{array}$ & & $\checkmark$ & \pm & \pm & - & $\begin{array}{l}\text { At } 3 \text { months, mean BCVA } \\
\text { improved by }+2.1 \text { lines } \\
(P=0.0 \mathrm{I})\end{array}$ \\
\hline \multirow[t]{2}{*}{ Arcinue et $\mathrm{a}^{25}$} & $\begin{array}{l}27 \text { eyes of } \\
25 \text { patients }\end{array}$ & 11 & $0.7 \mathrm{mg}$ & \pm & \pm & - & $\begin{array}{l}\text { No significant } \\
\text { differences in the BCVA } \\
\text { improvement between } \\
\text { the two arms }\end{array}$ \\
\hline & & 16 & $\begin{array}{l}0.59 \mathrm{mg} \\
\mathrm{FAi}\end{array}$ & \pm & \pm & - & \\
\hline Lam et $\mathrm{al}^{22}$ & 23 & & $0.7 \mathrm{mg}$ & \pm & \pm & - & $\begin{array}{l}0.76 \pm 0.08 \text { ( } 81 \% \text { gaining } \\
\text { one or more lines } \\
\text { of vision) }\end{array}$ \\
\hline $\begin{array}{l}\text { Tomkins-Netzer } \\
\text { et } \mathrm{al}^{23}\end{array}$ & $\begin{array}{l}38 \text { eyes of } \\
27 \text { patients } \\
\text { treated } \\
\text { with } 61 \\
\text { implants }\end{array}$ & $\begin{array}{l}\text { I } 4 \text { eyes with } \\
\text { single implant } \\
24 \text { eyes with } \\
\text { multiple } \\
\text { implants ( } 36.9 \% \\
2 \text { implants, } \\
18.4 \% \\
3 \text { implants, } \\
5.2 \% \\
4 \text { implants, } \\
2.6 \% \\
6 \text { implants) }\end{array}$ & $0.7 \mathrm{mg}$ & \pm & \pm & - & $\begin{array}{l}2 \text { months: } 0.27 \pm 0.07 \text {, } \\
6 \text { months: } 0.43 \pm 0.12 \\
\text { Second implant has } \\
\text { similar effect as first } \\
\text { implant within I month. } \\
\text { Long-term accumulative } \\
\text { effect: continued } \\
\text { improvement in BCVA }\end{array}$ \\
\hline
\end{tabular}

Notes: Data presented as \pm SD. “-”, data not available; \pm , treatment was or was not administered based on physician's discretion; $\checkmark$, treatment administered.

Abbreviations: BCVA, best-corrected visual acuity; CFT, central foveal thickness; CME, cystoid macular edema; CMT, central macular thickness; CRT, central retinal thickness; CS, corticosteroids; Dex, dexamethasone; FAi, fluocinolone acetonide implant; MD, mean deviation; ME, macular edema. 


\begin{tabular}{|c|c|c|c|c|c|c|}
\hline $\begin{array}{l}\text { Mean CRT/CFT/ } \\
\text { CMT }(\mu \mathrm{m})\end{array}$ & ME & $\begin{array}{l}\text { Uveitis } \\
\text { activityl } \\
\text { vitreous haze } \\
\text { score }\end{array}$ & $\begin{array}{l}\text { Mean time to first } \\
\text { recurrence of } \\
\text { uveitis }\end{array}$ & $\begin{array}{l}\text { Uveitis } \\
\text { recurrence } \\
\text { rate }\end{array}$ & Reimplantation & Others \\
\hline \multirow{3}{*}{$\begin{array}{l}\text { Week } 8 \text { and } 26 \text { : } \\
\text { statistically significant } \\
\text { lower CMT compared } \\
\text { to baseline ( } P \leq 0.004) \text {. } \\
\text { Mean decrease from } \\
\text { baseline }>\text { sham at } \\
\text { week } 8 \text { but not } \\
\text { week } 26\end{array}$} & - & $\begin{array}{l}47 \% \text { score of } \\
0 \text { at week } 8\end{array}$ & - & - & - & - \\
\hline & - & $\begin{array}{l}36 \% \text { score of } 0 \\
\text { at week } 8\end{array}$ & - & - & - & - \\
\hline & - & $\begin{array}{l}12 \% \text { score of } 0 \\
\text { at week } 8\end{array}$ & - & - & - & - \\
\hline- & $\begin{array}{l}\text { No CME } \\
\text { detected in } \\
89 \% \text { of eyes } \\
\text { at I month } \\
\text { and } 72 \% \text { at } \\
3 \text { months }\end{array}$ & $\begin{array}{l}\text { Score } 0 \text { at all } \\
\text { months }\end{array}$ & $\begin{array}{l}\text { Median time to } \\
\text { recurrence of CME: } \\
20 \mathrm{I} \pm 62 \text { days }\end{array}$ & $\begin{array}{l}\text { Recurrence of } \\
\text { CME: } 65 \% \text { at } \\
6 \text { months, } 70 \% \\
\text { at } 12 \text { months }\end{array}$ & $\begin{array}{l}56 \% \geq 2 \text { implants. } \\
\text { Median time to } \\
\text { retreatment: } \\
300 \pm 7 \mid \text { days }\end{array}$ & - \\
\hline $\begin{array}{l}\text { I month: } 278.3 \pm 43.8 \text {, } \\
6 \text { months: } 3 \mid 4.3 \pm 72.6 \text {, } \\
\text { I } 2 \text { months: } \\
34 \mid .8 \pm 139.3 \\
(P=0.1254)\end{array}$ & - & $\begin{array}{l}\text { Rate of } \\
\text { improvement: } \\
24 / 1,000 \\
\text { person-months }\end{array}$ & - & $\begin{array}{l}0.5 / 100 \\
\text { person-months }\end{array}$ & $\begin{array}{l}45 \% \text { two } \\
\text { implants. Median } \\
\text { survival time for } \\
\text { second implant: } \\
\text { I } 3 \text { months }\end{array}$ & - \\
\hline $\begin{array}{l}\text { I month: } \\
298.1 \pm \mid 25.8 \\
6 \text { months: } \\
276.6 \pm 125.8 \\
12 \text { months: } \\
248.6 \pm 48.4(P=0.163)\end{array}$ & & $\begin{array}{l}\text { Rate of } \\
\text { improvement: } \\
47 / 1,000 \\
\text { person-months }\end{array}$ & & $\begin{array}{l}1.7 / 100 \\
\text { person-months. } \\
3.16 \text { times } \\
\text { more at risk } \\
\text { of recurrence } \\
(P=0.41)\end{array}$ & $\begin{array}{l}\text { I2.5\% two } \\
\text { implants. Median } \\
\text { survival time for } \\
\text { second implant: } \\
28 \text { months }\end{array}$ & \\
\hline $\begin{array}{l}\text { Peak improvement in } \\
\text { CRT was } 274.3 \pm 42.3 \\
\text { ( } 66.7 \% \text { had reduction } \\
\text { in central retinal } \\
\text { thickness and } \\
\text { improved vision) }\end{array}$ & - & - & - & - & - & - \\
\hline CRT at I month: & $50 \%$ eyes & $93 \%$ score of 0 & Median time & $69 \%$ & - & - \\
\hline $\begin{array}{l}\text { Change of }-263 \pm 44 \\
(P=0.003)\end{array}$ & $\begin{array}{l}\text { persistent } \\
\text { ME }\end{array}$ & - & $\begin{array}{l}6 \text { months } \\
\text { (range, } 2-42 \text { months) }\end{array}$ & $\begin{array}{l}\text { Second implant: } \\
48 \%\end{array}$ & & \\
\hline $\begin{array}{l}6 \text { months: }-127 \pm 52 \\
(P=0.01) \text {, stable until }\end{array}$ & - & & $\begin{array}{l}\text { Second implantation: } \\
\text { median time }\end{array}$ & & & \\
\hline 12 months & & & 6 months & & & \\
\hline $\begin{array}{l}\text { Second implant similar } \\
\text { effect as first. Long- } \\
\text { term accumulative } \\
\text { effect: significant } \\
\text { improvement and } \\
\text { stabilization of CRT }\end{array}$ & & & (range, I-12 months) & & & \\
\hline
\end{tabular}


Table I 2 Studies on dexamethasone implants (adverse effects)

\begin{tabular}{|c|c|c|c|c|c|c|}
\hline \multirow[t]{2}{*}{ Study } & \multirow{2}{*}{$\begin{array}{l}\text { Number of } \\
\text { participants/eyes }\end{array}$} & \multirow[t]{2}{*}{ No of eyes } & \multicolumn{3}{|c|}{ Intervention } & \multirow{2}{*}{$\begin{array}{l}\text { Adverse events } \\
\text { Ocular } \\
\text { Cataracts }\end{array}$} \\
\hline & & & $\begin{array}{l}\text { DEX } \\
\text { implant }\end{array}$ & $\begin{array}{l}\text { Systemic } \\
\text { CS (unless } \\
\text { otherwise } \\
\text { stated) }\end{array}$ & $\begin{array}{l}\text { Immuno- } \\
\text { suppression }\end{array}$ & \\
\hline \multirow[t]{3}{*}{ Lowder et $\mathrm{al}^{20}$} & $\begin{array}{l}229 \text { (right eye as } \\
\text { study eye) }\end{array}$ & 77 & $0.7 \mathrm{mg}$ & \pm & \pm & $15 \%$ \\
\hline & & 76 & $0.35 \mathrm{mg}$ & \pm & \pm & $12 \%$ \\
\hline & & 76 & $\begin{array}{l}\text { Sham } \\
\text { procedure }\end{array}$ & \pm & \pm & $7 \%$ \\
\hline Khurana and Porco ${ }^{21}$ & 18 eyes ( 13 patients) & & $\checkmark$ & \pm & \pm & None \\
\hline \multirow[t]{2}{*}{ Arcinue et a ${ }^{25}$} & 27 eyes of 25 patients & 11 & $0.7 \mathrm{mg}$ & \pm & \pm & $50 \%$ \\
\hline & & 16 & - & $0.59 \mathrm{mg} \mathrm{FAi}$ & \pm & $100 \%$ \\
\hline Lam et $\mathrm{al}^{22}$ & 23 & & $0.7 \mathrm{mg}$ & \pm & \pm & $\begin{array}{l}5 \% \text { phakic eyes } \\
\text { developed cataract. } \\
45.5 \% \text { cataract } \\
\text { surgery }\end{array}$ \\
\hline \multirow[t]{5}{*}{ Tomkins-Netzer et $\mathrm{al}^{23}$} & $\begin{array}{l}38 \text { eyes of } 27 \text { patients } \\
\text { treated with }\end{array}$ & $\begin{array}{l}\text { I4 eyes with single } \\
\text { implant }\end{array}$ & $0.7 \mathrm{mg}$ & \pm & \pm & \\
\hline & 61 implants & 24 eyes with multiple & & & & First implantation: \\
\hline & & implants $(36.9 \%$ & & & & $5 \%$ phakic eyes. \\
\hline & & Two implants, $18.4 \%$ & & & & Repeat implantation: \\
\hline & & $\begin{array}{l}\text { Three implants, } 5.2 \% 4 \\
\text { implants, } 2.6 \% 6 \text { implants) }\end{array}$ & & & & $5 \%$ phakic eyes \\
\hline
\end{tabular}

Notes: “-”, data not available; \pm , treatment was or was not administered based on physician's discretion; $\checkmark$, treatment administered.

Abbreviations: DEX, dexamethasone; FAi, fluocinolone acetonide implant; IOP, intraocular pressure; CS, corticosteroids.

vasoproliferative conditions such as diabetic retinopathy. Since CNV is also a well-known sight-threatening complication of NIU, various studies have evaluated the efficacy and safety of intravitreal anti-VEGF in the treatment of CNV and CME secondary to NIU. ${ }^{28-30}$ Some studies have also studied the use of intravitreal anti-VEGF in the treatment of CME. ${ }^{31-33}$ Data from seven studies were gathered. All were retrospective case studies with the exception of one randomized controlled trial. Tables $13-16$ provide the summary of these studies.

In a retrospective multicenter case study of 84 eyes receiving either 1.25 or $2.5 \mathrm{mg}$ of intravitreal bevacizumab
(IVB), Mansour et al reported that IVB resulted in significant visual improvement of 2.5 lines as well as decrease in CRT in a short term. ${ }^{34}$ However, BVCA worsened in 10.7\% of the eyes, but no possible reason was discussed. Macular hemorrhage occurred in one eye, but no other systemic or ocular adverse events occurred. As this was a multicenter retrospective study, the researchers were unmasked and the given doses of IVB were inconsistent.

Another retrospective study by Mansour et al focused on the long-term effects of IVB on 99 uveitic eyes with $\mathrm{CNV}$ refractory to systemic treatment and reported that IVB resulted in long-term significant improvement in mean 


\begin{tabular}{|c|c|c|c|c|c|}
\hline \multirow{3}{*}{\multicolumn{2}{|c|}{ Raised IOP }} & \multirow{4}{*}{ Others } & \multirow{4}{*}{ Systemic } & \multirow{4}{*}{$\begin{array}{l}\text { Reasons for } \\
\text { removal of } \\
\text { implants } \\
\text { (if any) }\end{array}$} & \multirow{4}{*}{$\begin{array}{l}\text { Other } \\
\text { comments }\end{array}$} \\
\hline & & & & & \\
\hline & & & & & \\
\hline $\begin{array}{l}>10 \mathrm{mmHg} / \text { requiring } \\
\text { medications }\end{array}$ & $\begin{array}{l}\text { Requiring } \\
\text { surgery }\end{array}$ & & & & \\
\hline $\begin{array}{l}23 \% \text { requiring medication, } \\
7.1 \% \mathrm{IOP}>25 \mathrm{mmHg}\end{array}$ & None & None & \multirow{3}{*}{$\begin{array}{l}\text { Conjunctival hemorrhage, } \\
\text { ocular discomfort, eye } \\
\text { pain, iridocyclitis. I case of } \\
\text { suspected endophthalmitis or } \\
\text { uveitis flare in } 0.7 \mathrm{mg} \text { implant } \\
\text { group. } 4 \text { retinal detachments }\end{array}$} & - & - \\
\hline $8.7 \%>25 \mathrm{mmHg}$ & None & $1 \%$ & & - & - \\
\hline $4.2 \%>25 \mathrm{mmHg}$ & None & None & & - & - \\
\hline $10 \%$ had increased IOP & None & $\begin{array}{l}\text { I I \% eyes had } \geq 1 \text { episode } \\
\text { of IOP }>25 \mathrm{mmHg} \text { within } \\
\text { first } 3 \text { months, all effectively } \\
\text { managed with topical } \\
\text { medications }\end{array}$ & None & - & \\
\hline None & None & None & $\begin{array}{l}\text { I implant migration into } \\
\text { the anterior chamber, I } \\
\text { intralenticular location of the } \\
\text { Ozurdex implant, possible } \\
\text { endophthalmitis }\end{array}$ & - & - \\
\hline $44 \%$ & & None & $\begin{array}{l}\text { I postoperative hypotony, } \\
\text { cyclodialysis cleft, choroidal } \\
\text { effusion, and hypotony }\end{array}$ & - & - \\
\hline $\begin{array}{l}22.7 \%>10 \mathrm{mmHg} \text { increase, } \\
8.7 \% \text { require topical eye } \\
\text { drops }\end{array}$ & None & None & $5 \%$ retinal detachment & - & $\begin{array}{l}\text { I eye with uveitis } \\
\text { was switched to } \\
\text { FAi as a longer- } \\
\text { acting intraocular } \\
\text { steroid was } \\
\text { deemed needed }\end{array}$ \\
\hline $\begin{array}{l}\text { First implantation: } 7.9 \% \\
\text { increased IOP } \\
\text { of }>21 \mathrm{mmHg} \text { after } \\
2 \text { months. Second } \\
\text { implantation: } 17.9 \% \\
\text { increased IOP of }>25 \mathrm{mmHg}\end{array}$ & None & None & $\begin{array}{l}\text { After first implant: I eye with } \\
\text { implant migration }\end{array}$ & - & - \\
\hline
\end{tabular}

BCVA and CRT with an average of 3.6 injections up to the follow-up period of 24 months. ${ }^{35}$ The angiographic regression pattern correlated with the primary disease, and complete regression was associated with younger age. However, this correlation was not found with regard to the location of CNV or the concomitant intake of immunosuppressive therapy. Ocular adverse events were observed in this study: submacular fibrosis in three eyes, submacular hemorrhage in one eye, and mild ocular hypertension in another. Yet another retrospective study of 81 eyes by Mansour et $\mathrm{al}^{34}$ showed the improvement of BCVA and CRT after the use of IVB with a median of three injections in 3 years. Adverse events observed were submacular fibrosis, retinal pigment epithelial tear, and macular ischemia in the context of vasculitis.

Also focusing on evaluating the long-term effects of IVB, a retrospective case series of 15 uveitic eyes with CNV refractory to systemic therapy over 17.6 months by Julián et $\mathrm{al}^{29}$ reported that $1.25 \mathrm{mg} / 0.05 \mathrm{~mL}$ IVB resulted in a statistically significant improvement of BCVA and CRT in most of the eyes after the first month and at the fourth month. However, this effect was transient as BCVA and CRT in the later months did not show statistically significant difference. Notably, BCVA and CRT also worsened in a few eyes. Most of the eyes had more than one injection 


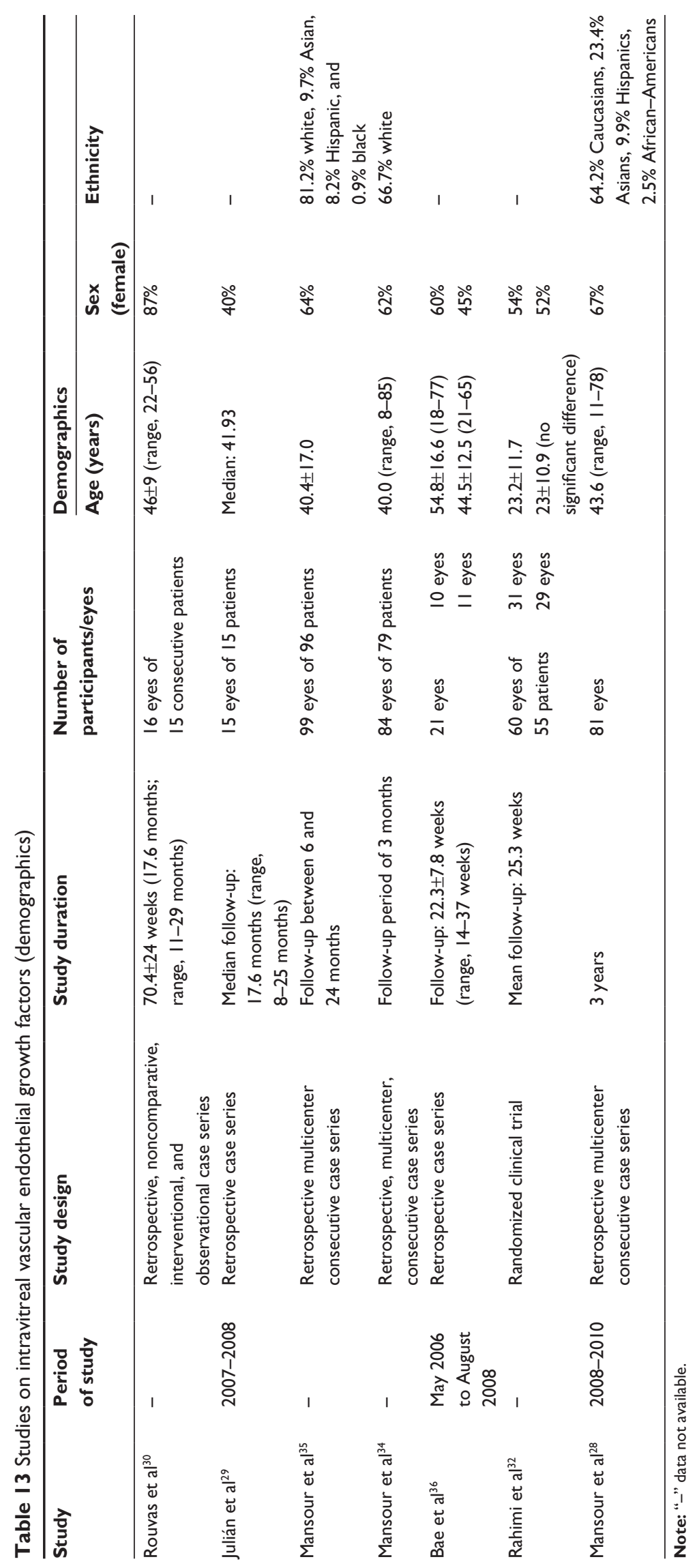


given with the mean number being 4.25 at a frequency of one every 12.97 weeks. No adverse ocular or systemic side effects were observed in this retrospective study. Largerscale studies were recommended to evaluate the correlation between the number of injections and the subgroups of uveitis. The discrepancy in the findings of this study and Mansour et $\mathrm{al}^{34}$ with regard to the long-term effect of IVB could be due to the fact that the sample size is different and that the doses of IVB given were inconsistent between the two. Furthermore, their inclusion criteria differed slightly with Mansour et al's study including uveitic eyes with active inflammation.

The use of another anti-VEGF agent, ranibizumab in the treatment of inflammatory CNV was studied by Rouvas et al. ${ }^{30}$ In this retrospective study of 16 eyes over a mean of 17.6 months, most patients had a significant improvement in BCVA with no patients showing deterioration following an injection of $0.5 \mathrm{mg}$ ranibizumab. ${ }^{30}$ There was also a significant decrease in CRT. Although all eyes demonstrated regression of $\mathrm{CNV}, 68.8 \%$ of eyes developed retinal pigment epithelial atrophy in the surrounding of the regressed CNV.

Several comparative studies were performed to study the efficacy and safety of IVB in comparison with IVTA in the treatment of uveitic macular edema. In a retrospective comparative study, Bae et al reported that both $1.25 \mathrm{mg}$ IVB and $4 \mathrm{mg}$ IVTA resulted in an improvement in BCVA and CRT, which peaked in week 4 but deteriorated thereafter. ${ }^{36}$ The improvement in BCVA was greater in IVT, but the difference did not reach statistical significance. Of note, IVB resulted in a significantly larger gain in BCVA in Behçet's uveitis as compared with non-Behçet's uveitis; however, the exact details were not provided in the study. The median period of effect of the IVB was 16 weeks as compared with 30 weeks for IVTA. With regard to side effects, an increase in IOP $>5 \mathrm{mmHg}$ was observed five times more frequently in eyes treated with IVTA. However, this was a retrospective comparative study that had a small sample size and short duration of study.

Rahimi et al also compared $1.25 \mathrm{mg}$ IVB and $4 \mathrm{mg}$ IVTA on their effect on uveitic CME that was not responding to topical corticosteroids in a randomized comparative trial. ${ }^{32}$ Both IVB and IVTA resulted in improvements in BCVA that peaked at 6 months with no statistically significant difference between the two. Both the drugs also resulted in a statistically significant decrease in CRT; however, IVTA was significantly better than IVB in this aspect. Regarding adverse effects, IVTA resulted in statistically significantly greater rise in IOP as opposed to IVB, which had minimal effect on IOP.

The results of these studies demonstrated that intravitreal anti-VEGF agents, in particular bevacizumab, resulted in improvement in BCVA and CRT. However, the effects tend to be short-lasting with a need for repeated injections. With regard to adverse events, submacular fibrosis appears to be related to the use of IVB. Side effects commonly seen in intravitreal corticosteroids were not evident with IVB. However, there was variation in the medication dosages in these studies. Furthermore, common limitations in these studies were that most of the participants were still on systemic therapy during the course of the study, and most of these studies were retrospective. Therefore, long-term and larger-scale randomized controlled trials are needed to establish the efficacy and duration of action as well as safety and side effect profile of intravitreal anti-VEGF agents in the treatment of NIU.

\section{Intravitreal methotrexate}

In NIU, methotrexate is usually used for systemic immunosuppression. It is an anti-metabolite that is commonly used for the treatment of rheumatoid arthritis and cancer. Intravitreal methotrexate was first introduced for the treatment of intraocular lymphoma. Taylor et al investigated the use of intravitreal methotrexate in a pilot prospective interventional case series study and in a multicenter retrospective case series study. ${ }^{37,38}$ Tables $17-19$ provide the summary of studies regarding intravitreal methotrexate.

In the pilot study of 15 eyes in 15 patients, Taylor et al reported that intravitreal methotrexate resulted in an improvement in BCVA and ocular inflammation as well as CRT with significant effects seen within 1 week except in two patients. ${ }^{37}$ Systemic medications were also reduced in patients who responded. A relapse occurred in $30 \%$ of patients at a median time of 4 months. A repeat injection in these patients showed improvement within 2 months. Importantly, there were no instances of raised IOP following intravitreal methotrexate even though all patients had raised IOP secondary to corticosteroids (steroid responders). Corneal epitheliopathy occurred in one pseudophakic patient while opacification of lens occurred in another patient (although it was postulated to be unrelated to the methotrexate injection).

The multicenter retrospective case series study consisted of 38 uveitic eyes. ${ }^{38}$ In this study, $79 \%$ of eyes responded to the intravitreal methotrexate with improved visual acuity, 
Table 14 Studies on intravitreal vascular endothelial growth factors (clinical features)

\begin{tabular}{|c|c|c|c|c|}
\hline \multirow[t]{2}{*}{ Study } & \multicolumn{4}{|c|}{ Clinical features of participants } \\
\hline & Diagnosis of study eye & Details & $\begin{array}{l}\text { Laterality } \\
\text { of condition }\end{array}$ & $\begin{array}{l}\text { Duration } \\
\text { of uveitis }\end{array}$ \\
\hline Rouvas et al $\left.\right|^{30}$ & $\begin{array}{l}\text { NIU with CNV and no } \\
\text { active inflammation }\end{array}$ & $\begin{array}{l}25 \% \text { toxoplasmosis, } 12.5 \% \text { serpiginous } \\
\text { choroidopathy, } 31.25 \% \text { punctate inner } \\
\text { choroidopathy, } 18.75 \% \text { multifocal choroiditis, } \\
12.5 \% \text { scleroderma. } 68.75 \% \text { subfoveal } C N V \text {, } \\
18.75 \% \text { juxtafoveal } C N V, 12.5 \% \text { extrafoveal CNV }\end{array}$ & - & - \\
\hline Julián et a ${ }^{29}$ & $\begin{array}{l}\text { NIU with CNV and no } \\
\text { active inflammation }\end{array}$ & $\begin{array}{l}47 \% \text { multifocal choroiditis and panuveitis, } \\
13 \% \text { ampiginous choroiditis, } 40 \% \text { remaining } \\
\text { serpiginous choroiditis, sympathetic ophthalmia, } \\
\text { Vogt-Koyanagi-Harada syndrome, punctuate } \\
\text { inner choroidopathy, tuberculosis and idiopathic } \\
\text { inflammation. } 87 \% \text { subfoveal CNV and } 13 \% \\
\text { peripapillary CNV }\end{array}$ & - & - \\
\hline Mansour et a ${ }^{35}$ & $\begin{array}{l}\text { Eyes with inflammatory } \\
\text { ocular neovascularization. } \\
28 \% \text { with active } \\
\text { inflammation. Resistant to } \\
C S \pm \text { immunosuppression }\end{array}$ & $\begin{array}{l}23 \% \text { punctate inner choroidopathy, } 19 \% \\
\text { multifocal choroiditis with panuveitis, I3\% ocular } \\
\text { histoplasmosis, I2\% idiopathic, } 9 \% \text { serpiginous } \\
\text { choroiditis, } 6 \% \text { Vogt-Koyanagi-Harada disease, } \\
5 \% \text { ocular toxoplasmosis, } 4 \% \text { Eales disease, } \\
2 \% \text { sarcoidosis, } 2 \% \text { sympathetic ophthalmia, } \\
2 \% \text { tuberculosis, I\% acute placoid pigment } \\
\text { epitheliopathy, and I\% birdshot choroiditis. } \\
\text { CNV mean I.3 disc diameters (range, } 0.25-5 \text { ). } \\
49 \% \text { subfoveal, } 38 \% \text { juxtafoveal, } 6 \% \text { peripapillary, } \\
6 \% \text { NVD/NVE }\end{array}$ & $3 \%$ bilateral & - \\
\hline Mansour et $\mathrm{al}^{34}$ & $\begin{array}{l}\text { Eyes with inflammatory } \\
\text { ocular neovascularization. } \\
27.4 \% \text { with active } \\
\text { inflammation. Resistant to } \\
C S \pm \text { immunosuppression }\end{array}$ & $\begin{array}{l}\text { I7.9\% multifocal choroiditis with panuveitis; } \\
\text { I7.9\% punctate inner choroidopathy; I5.5\% } \\
\text { ocular histoplasmosis; II.9\% idiopathic uveitis; } \\
6 \% \text { Vogt-Koyanagi-Harada, } 6 \% \text { serpiginous } \\
\text { choroiditis, } 6 \% \text { retinal vasculitis; } 4.8 \% \text { Eales disease; } \\
3.6 \% \text { pars planitis, } 3.6 \% \text { ocular toxoplasmosis; } \\
2.4 \% \text { tuberculosis, } 2.4 \% \text { sarcoidosis; I.2\% birdshot } \\
\text { choroiditis. } 40.5 \% \text { juxtafoveal CNV, } 40.5 \% \text { subfoveal } \\
\text { CNV, } 9.5 \% \text { peripapillary CNV, I3.1\% NVD/NVE }\end{array}$ & $7 \%$ bilateral & $\begin{array}{l}30.6 \text { months (range, } \\
\text { I- } 240 \text { months) at } \\
\text { study entry }\end{array}$ \\
\hline Bae et $\mathrm{al}^{36}$ & $\begin{array}{l}\text { NIU with CME }>3 \text { months } \\
\text { despite conventional } \\
\text { treatment }\end{array}$ & $\begin{array}{l}50 \% \text { eyes with Behçet's disease } \\
55 \% \text { eyes with Behçet's disease }\end{array}$ & $\begin{array}{l}40 \% \text { bilateral } \\
27 \% \text { bilateral }\end{array}$ & - \\
\hline Rahimi et al ${ }^{32}$ & $\begin{array}{l}\text { CME refractory to } \\
\text { conventional topical } \\
\text { medication }\end{array}$ & $\begin{array}{l}40 \% \text { intermediate uveitis, } 25 \% \text { pars planitis, } 12 \% \\
\text { idiopathic anterior uveitis, } 10 \% \text { Behçet's disease, } \\
7 \% \text { idiopathic posterior uveitis, } 3 \% \text { Vogt-Koyanagi- } \\
\text { Harada syndrome, } 3 \% \text { idiopathic panuveitis and } \\
\text { vasculitis }\end{array}$ & - & - \\
\hline Mansour et $\mathrm{a}^{28}$ & $\begin{array}{l}\text { Inflammatory ocular } \\
\text { neovascularization } \\
\text { refractory to standard } \\
\text { therapy. } 16 \% \text { of eyes with } \\
\text { active uveitis }\end{array}$ & $\begin{array}{l}29.6 \% \text { punctate inner choroidopathy, } 14.8 \% \\
\text { multifocal choroiditis with panuveitis, } 23.5 \% \text { ocular } \\
\text { histoplasmosis, } 12.3 \% \text { serpiginous choroiditis, } \\
4.9 \% \text { Vogt-Koyanagi-Harada syndrome, } 6.2 \% \text { ocular } \\
\text { toxoplasmosis, and } 3.8 \% \text { vasculitis. } 61.7 \% \text { subfoveal } \\
\text { CNV, 32.1\% juxtafoveal, } 9.9 \% \text { peripapillary, } \\
6.2 \% \text { NVD/NVE }\end{array}$ & $0 \%$ bilateral & - \\
\hline
\end{tabular}

Note: "-”, data not available.

Abbreviations: CFT, central foveal thickness; CME, cystoid macular edema; CMT, central macular thickness; CNV, choroidal neovascularization; CRT, central retinal thickness; CS, corticosteroids; logMAR, logarithm of Minimal Angle of Resolution; ME, macular edema; NIU, noninfectious uveitis; NVD, neovascularization of disc; NVE, neovascularization elsewhere; VA, visual acuity. 


\begin{tabular}{|c|c|c|c|c|c|c|}
\hline $\begin{array}{l}\text { Presence of } \\
\text { other ocular } \\
\text { conditions }\end{array}$ & $\begin{array}{l}\text { Previous uveitis } \\
\text { treatment }\end{array}$ & $\begin{array}{l}\text { Presence } \\
\text { of systemic } \\
\text { conditions }\end{array}$ & $\begin{array}{l}\text { Mean } \\
\text { baseline VA } \\
\text { (logMAR) }\end{array}$ & $\begin{array}{l}\text { Mean } \\
\text { baseline } \\
\text { vitreous } \\
\text { haze }\end{array}$ & $\begin{array}{l}\text { Mean baseline } \\
\text { CRT/CFT/CMT } \\
(\mu \mathrm{m})\end{array}$ & $\begin{array}{l}\text { Other baseline } \\
\text { values }\end{array}$ \\
\hline- & $\begin{array}{l}\text { Treated with topical } \\
\text { and systemic CS, } \\
\text { sub-Tenon's steroid } \\
\text { injections, and } \\
\text { systemic cyclosporine } \\
\text { where appropriate }\end{array}$ & - & $0.9 \pm 0.4$ & - & CFT: $285 \pm 20$ & - \\
\hline- & $\begin{array}{l}\text { Mean time under } \\
\text { treatment: } 30 \text { months } \\
\text { for systemic } \\
\text { immunosuppression, } \\
44 \text { months for CS }\end{array}$ & - & 0.53 & - & CFT: $239.06 \pm 47.68$ & - \\
\hline- & - & - & $0.65 \pm 0.44$ & - & CFT: $338 \pm 87$ & - \\
\hline- & $\begin{array}{l}\text { I7\% systemic } \\
\text { immunosuppressive } \\
\text { agents, } 49 \% \text { oral CS, } \\
10 \% \text { sub-Tenon's CS, } \\
13 \% \text { intravitreal CS }\end{array}$ & - & 0.68 & - & CFT: 346 & $\begin{array}{l}\text { CNV size: } \\
\text { mean I.3 disc } \\
\text { diameters (range, } \\
0.25-4 \text { disc } \\
\text { diameters) }\end{array}$ \\
\hline $\begin{array}{l}\text { No glaucoma or } \\
\text { other macular } \\
\text { abnormalities }\end{array}$ & $\begin{array}{l}\text { No previous } \\
\text { treatment for CME }\end{array}$ & $\begin{array}{l}\text { No } \\
\text { hypertension } \\
\text { or diabetes } \\
\text { mellitus }\end{array}$ & $\begin{array}{l}0.73 \pm 0.4 I \\
0.73 \pm 0.33\end{array}$ & - & $\begin{array}{l}\text { CFT: } 537 \pm 214 \\
\text { CFT: } 594 \pm 151\end{array}$ & - \\
\hline \multirow[t]{2}{*}{ Nil } & - & - & $0.47 \pm 0.18$ & $\begin{array}{l}\text { Mean vitreous } \\
\text { reaction } \\
\text { grade: } 2.00\end{array}$ & CMT: $309.87 \pm 52.43$ & $\begin{array}{l}\text { Mean grade for } \\
\text { anterior chamber } \\
\text { reaction: } 0.7\end{array}$ \\
\hline & & & $0.48 \pm 0.22$ & $\begin{array}{l}\text { Mean vitreous } \\
\text { reaction } \\
\text { grade: } 1.24\end{array}$ & CMT: $295.62 \pm 33.19$ & $\begin{array}{l}\text { Mean grade for } \\
\text { anterior chamber } \\
\text { reaction: } 0.9\end{array}$ \\
\hline- & $\begin{array}{l}38.6 \% \text { on oral } \\
\text { CS; } 4.9 \% \text { sub- } \\
\text { Tenon's CS, II.I\% } \\
\text { intraocular CS, } 21 \% \\
\text { immunosuppressive } \\
\text { agents }\end{array}$ & - & $0.70 \pm 0.43$ & - & CFT: $322.5 \pm 101.8$ & $\begin{array}{l}\text { CNV size: } \\
\text { I.19 } 19.79 \text { disc } \\
\text { diameters }\end{array}$ \\
\hline
\end{tabular}


Table 15 Studies on intravitreal vascular endothelial growth factors (outcomes)

\begin{tabular}{|c|c|c|c|c|c|c|}
\hline \multirow[t]{2}{*}{ Study } & \multirow{2}{*}{\multicolumn{2}{|c|}{$\begin{array}{l}\text { Number of } \\
\text { participants/eyes }\end{array}$}} & \multicolumn{3}{|l|}{ Intervention } & \multirow{2}{*}{$\begin{array}{l}\text { Outcomes measured } \\
\text { BCVA }\end{array}$} \\
\hline & & & $\begin{array}{l}\text { Anti-VEGF } \\
\text { injection }\end{array}$ & $\begin{array}{l}\text { Systemic } \\
\text { CS (unless } \\
\text { otherwise } \\
\text { stated) }\end{array}$ & Immunosuppression & \\
\hline $\begin{array}{l}\text { Roukas } \\
\text { et al }{ }^{30}\end{array}$ & $\begin{array}{l}16 \text { eyes of } \\
15 \text { consecut } \\
\text { patients }\end{array}$ & & $\begin{array}{l}0.5 \mathrm{mg} \\
\text { ranibizumab }\end{array}$ & - & - & $\begin{array}{l}\text { End of follow-up: } 0.6 \pm 0.4(P=0.000 I) \text {. } \\
\text { Improved in } 88 \% \text {, stable in } 12.5 \%\end{array}$ \\
\hline $\begin{array}{l}\text { Julián } \\
\text { et } \mathrm{al}^{29}\end{array}$ & $\begin{array}{l}15 \text { eyes fror } \\
15 \text { patients }\end{array}$ & & $\begin{array}{l}1.25 \mathrm{mg} \\
\text { bevacizumab }\end{array}$ & $\checkmark$ & $\begin{array}{l}60 \% \text { received } \\
\text { treatment }\end{array}$ & $\begin{array}{l}\text { I month postinjection: } 0.29 .80 \% \text { of eyes } \\
\text { improved, } 20 \% \text { worsened. Statistically } \\
\text { significant positive difference between } \\
\text { initial BCVA and } 4 \text { months BCVA but not } \\
\text { at } 8,12,16 \text { months }\end{array}$ \\
\hline $\begin{array}{l}\text { Mansour } \\
\text { et } \mathrm{al}^{35}\end{array}$ & $\begin{array}{l}99 \text { eyes of } \\
96 \text { patients }\end{array}$ & & $\begin{array}{l}33.3 \% 2.5 \mathrm{mg} \\
\text { bevacizumab, } \\
66.6 \% \\
1.25 \mathrm{mg} \\
\text { bevacizumab }\end{array}$ & \pm & \pm & $\begin{array}{l}6 \text { months: } 0.43 \pm 0.4 \mathrm{I}(P=0.000), 12 \text { months: } \\
0.40 \pm 0.37(P=0.000), 18 \text { months: } 0.37 \pm 0.4 \mathrm{I} \\
(P=0.00 \mathrm{I}), 24 \text { months: } 0.32 \pm 0.32(P=0.0 \mathrm{I} 3)\end{array}$ \\
\hline $\begin{array}{l}\text { Mansour } \\
\text { et } \mathrm{al}^{34}\end{array}$ & $\begin{array}{l}84 \text { eyes of } \\
79 \text { patients }\end{array}$ & & $\begin{array}{l}45 \% 2.5 \mathrm{mg} \\
\text { bevacizumab, } \\
55 \% 1.25 \mathrm{mg} \\
\text { bevacizumab }\end{array}$ & \pm & \pm & $0.44(P<0.00 \mathrm{I}), \mathrm{BCVA}$ worsened in $10.7 \%$ \\
\hline \multirow[t]{2}{*}{$\begin{array}{l}\text { Bae } \\
\text { et } \mathrm{al}^{36}\end{array}$} & 21 eyes & 10 eyes & $\begin{array}{l}\text { I.25 mg } \\
\text { intravitreal } \\
\text { bevacizumab }\end{array}$ & \pm & \pm & $\begin{array}{l}\text { Best improvement at } 4 \text { weeks of } \\
0.26 \pm 0.22 \text {. BCVA worsened at } 12 \text { weeks } \\
\text { but still improved from baseline ( } P<0.00 \mathrm{I}) \text {. } \\
\text { Significantly better improvement of BCVA } \\
\text { in Behçet's uveitis than in non-Behçet's } \\
\text { uveitis }(P=0.045)\end{array}$ \\
\hline & & II eyes & 4 mg IVTA & \pm & \pm & $\begin{array}{l}\text { Best improvement at } 4 \text { weeks of } \\
0.35 \pm 0.19 \text {. No statistically significant } \\
\text { difference between BCVA change in eyes } \\
\text { treated with bevacizumab and IVTA }\end{array}$ \\
\hline \multirow[t]{2}{*}{$\begin{array}{l}\text { Rahimi } \\
\text { et al }{ }^{32}\end{array}$} & $\begin{array}{l}60 \text { eyes of } \\
55 \text { patients }\end{array}$ & 31 eyes & $\begin{array}{l}1.25 \mathrm{mg} \\
\text { bevacizumab }\end{array}$ & \pm & \pm (baseline) & $\begin{array}{l}\text { I month: } 0.14 \pm 0.08(P<0.00 \text { I }) \\
3 \text { months: } 0.06 \pm 0.06(P<0.00 \text { I }), 6 \text { months: } \\
0.03 \pm 0.04(P<0.00 \text { I })\end{array}$ \\
\hline & & 29 eyes & 4 mg IVTA & \pm & \pm (baseline) & $\begin{array}{l}\text { I month: } 0.15 \pm 0.08 \text { ( } P<0.00 \text { I), } 3 \text { months: } \\
0.07 \pm 0.06(P<0.00 \text { I), } 6 \text { months: } 0.03 \pm 0.04 \\
(P<0.00 \text { I). No statistically significant } \\
\text { difference in the two groups at all time } \\
\text { points }\end{array}$ \\
\hline $\begin{array}{l}\text { Mansour } \\
\text { et } \mathrm{al}^{28}\end{array}$ & 81 eyes & & $\begin{array}{l}72.8 \% 2.5 \mathrm{mg} \\
\text { bevacizumab, } \\
27.2 \% \\
1.25 \mathrm{mg} \\
\text { bevacizumab }\end{array}$ & \pm & \pm & $\begin{array}{l}3 \text { years: } 0.43 \pm 0.43 \text {, mean difference of } \\
0.27 \pm 0.46(P<0.00 I)\end{array}$ \\
\hline
\end{tabular}

Notes: “-”, data not available; \pm , treatment was or was not administered based on physician's discretion; $\checkmark$, treatment administered.

Abbreviations: BCVA, best-corrected visual acuity; CFT, central foveal thickness; CMT, central macular thickness; CNV, choroidal neovascularization; CRT, central retinal thickness; CS, corticosteroids; IVTA, intravitreal triamcinolone acetonide; MD, mean deviation; ME, macular edema; NIU, noninfectious uveitis; NVD, neovascularization of disc; NVE, neovascularization elsewhere; VEGF, vascular endothelial growth factors. 


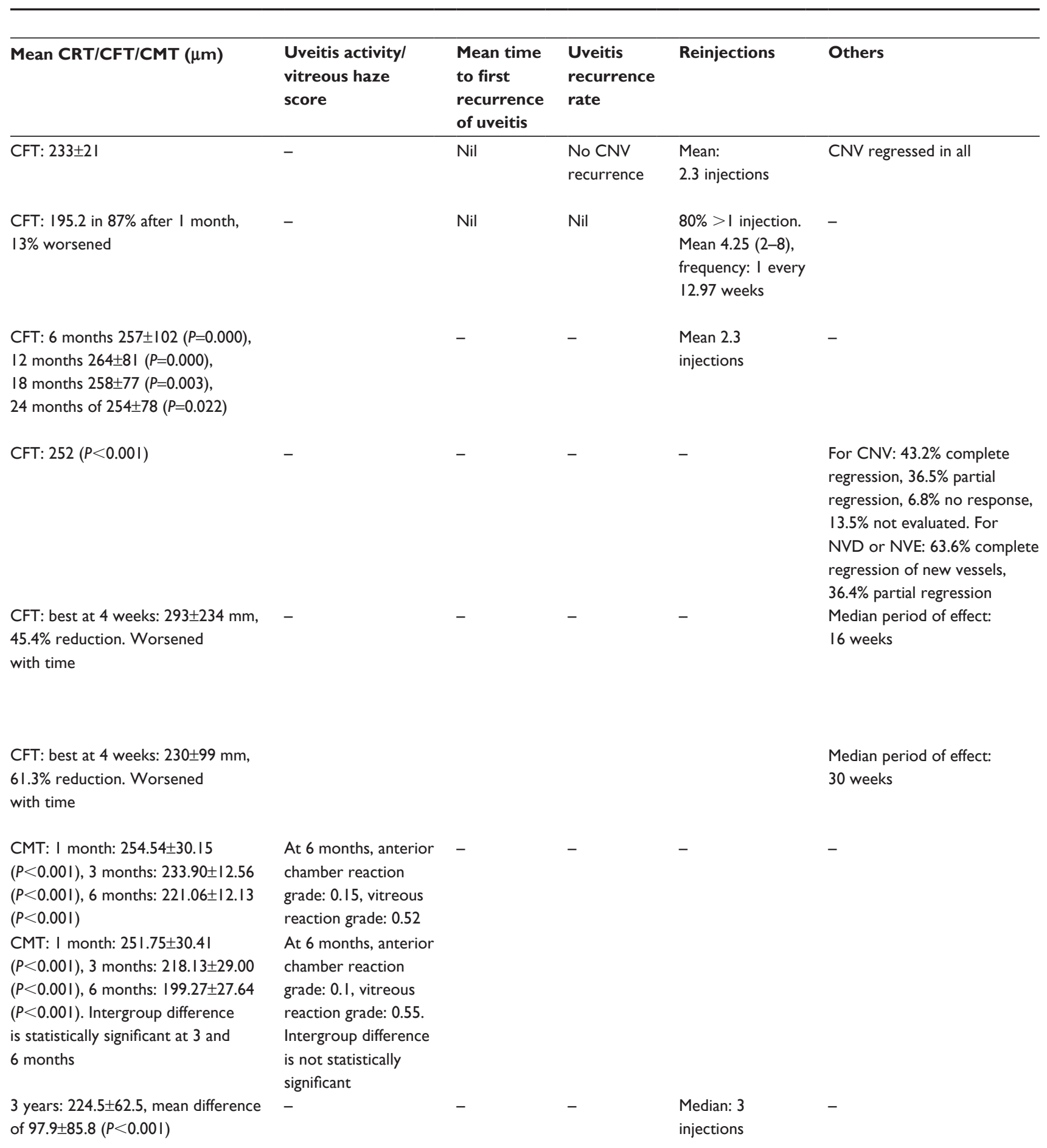




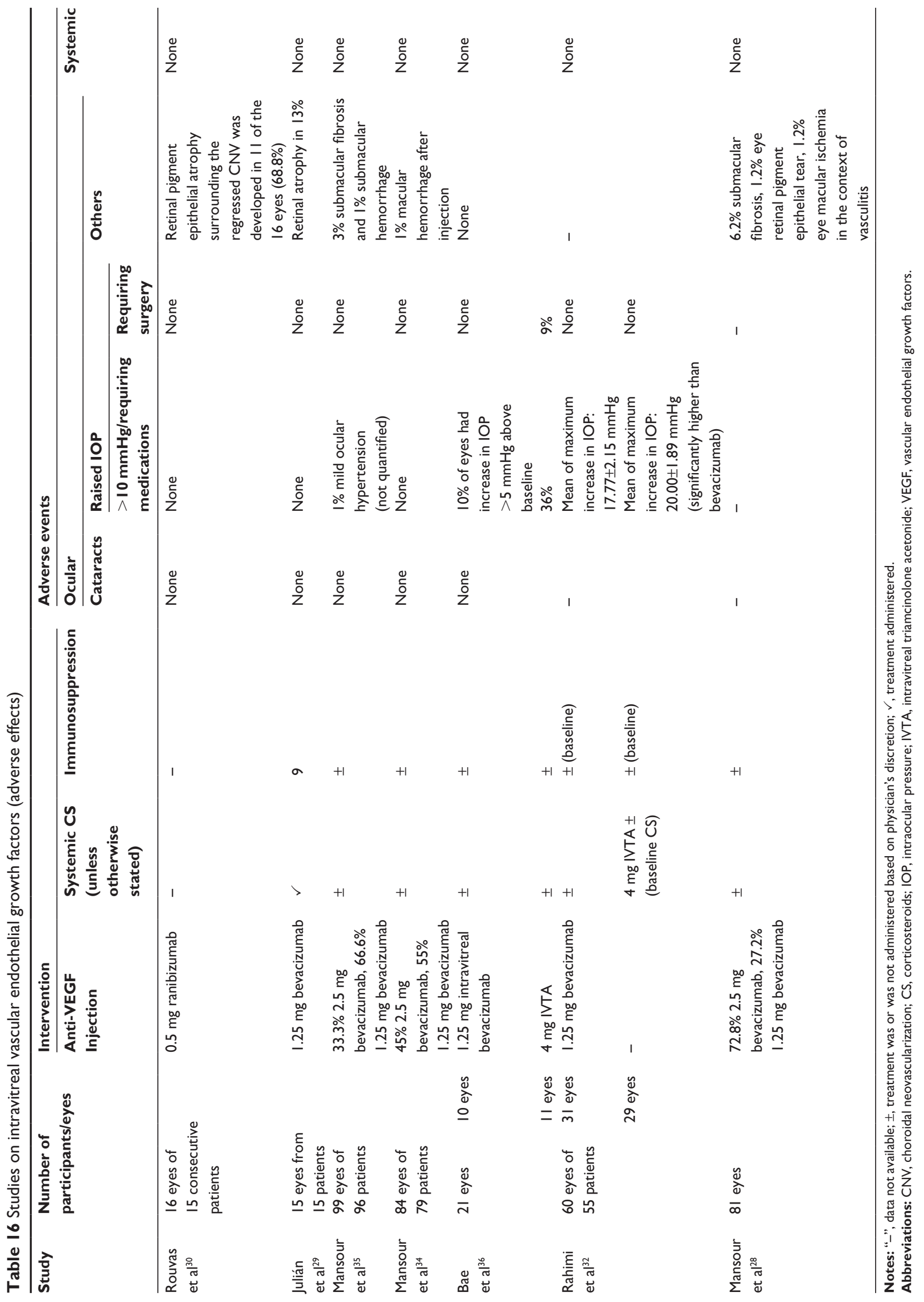


ocular inflammation, and macular thickness, which was consistent with the pilot study, and $27 \%$ of the eyes responded to intravitreal methotrexate relapsed after a median period of 3 months. However, a larger proportion of eyes entered an extended period of remission with no relapses throughout the period of follow-up. Taylor et $\mathrm{al}^{38}$ estimate the time of relapse for these eyes to be 17 months on the basis of the Kaplan-Meier estimate. Similar to the pilot study, 57\% of patients, who were on systemic therapy, were able to reduce their doses. Regarding adverse effects, only one eye had an increased IOP of $>25 \mathrm{mmHg}$, which was controlled with medications. No other ocular or systemic adverse events were recorded. However, short-term adverse events might not have been recorded, and this is a limitation of the retrospective study.

Intravitreal methotrexate appears to be a promising alternative to IVTA in unilateral diseases especially in phakic, steroid responders due to lower risk of increasing IOP and cataract formation. The extended remission effect by methotrexate in some patients should be explored in future studies. Thus far, studies have shown that intravitreal methotrexate alone may not be adequate to achieve remission in various uveitic entities and may be used as an adjunct with other forms of therapy. It is imperative to monitor the development of adverse events such as corneal decompensation, which may require treatment with topical folinic acid. Larger-scale and randomized controlled trials are definitely required for the establishment of efficacy and safety profile of intravitreal methotrexate. Contraindications to systemic methotrexate should also be observed.

\section{Intravitreal sirolimus}

Sirolimus, previously known as rapamycin, is one of the latest drugs in the spotlight for intravitreal treatment of NIU. It is a macrolide antibiotic, which is a potent immunosuppressant, and has antiproliferative properties. Tables $20-23$ provide the summary of studies regarding intravitreal sirolimus.

In 2003, the Sirolimus as a therapeutic Approach uVEitis (SAVE) study, a 12-month study of 30 patients, was initiated to evaluate the efficacy of intravitreal and subconjuctival sirolimus. ${ }^{39}$ The results of the 6-month interim analysis were reported by Nguyen et al. ${ }^{39}$ Sirolimus appeared to be well-tolerated in both the administration routes with improved inflammation and no ocular adverse events. Approximately $40 \%$ of eyes with active uveitis had improvement in inflammation with two or more steps difference in $\mathrm{VH}$ while $60 \%$ remained at baseline or had one-step improvement. However, some eyes did not have the potential to improve two steps, so the results may be skewed. Regarding its effects on visual acuity, improvement in BCVA was only seen in one-third of the patients with the rest maintaining stability and $20 \%$ had deterioration. This was attributed to the high baseline BCVA, with lower likelihood of improvement. Initial but nonsustained improvement in CRT was seen in some of the patients. Ibrahim et $\mathrm{al}^{39}$ reported the 1 year results of the SAVE study. A total number of 70 intravitreal sirolimus injections were administered to the 14 study eyes. Again, sirolimus, regardless of administration route, showed efficacy in reducing intraocular inflammation. At the end of 1 year, $70 \%$ of eyes with active uveitis showed a statistically significant reduction in two steps or more of $\mathrm{VH}$. In patients with inactive uveitis, $88 \%$ of eyes showed no change or one-step decrease in $\mathrm{VH}$, whereas $12 \%$ had a one-step increase. However, these changes in the eyes with inactive uveitis were not statistically significant. There was no statistically significant improvement in mean BCVA or change in CRT. Sirolimus appeared to be well-tolerated with repeated administration as well.

In 2015, the SAVE-2 study was initiated. This was a randomized comparative trial that compared, in 25 uveitic eyes, the effect of $440 \mu \mathrm{g}$ administered monthly as opposed to $880 \mu \mathrm{g}$ of intravitreal sirolimus administered every 2 months. The 6-month interim results as reported by Sepah et al were that low-dose sirolimus $(440 \mu \mathrm{g})$ appeared to have an advantage in reducing uveitic macular edema. ${ }^{40}$ However, both the doses seemed to be equally efficacious in the reduction of VH. Results of the SAVE-2 study are awaited.

In addition, there are ongoing multicenter, randomized, double-masked Phase III studies (SAKURA study), which are investigating the efficacy and tolerability of three doses of intravitreal sirolimus: $44 \mu \mathrm{g}, 440 \mu \mathrm{g}$, and $880 \mu \mathrm{g}$ administered every 2 months in the management of NIU in 347 patients. ${ }^{41}$ Srivastava et $\mathrm{al}^{42}$ presented the data for the primary endpoint of this study: the percentage of eyes with a VH score of 0 at month 5. It was reported that $440 \mu \mathrm{g}$ sirolimus was found to be significantly better than the other doses in achieving the primary endpoint, with $22.8 \%$ of eyes in the therapeutic arm achieving a $\mathrm{VH}$ score of 0 as compared with $10.3 \%$ in the $44 \mu \mathrm{g}$ arm and $16.6 \%$ in the $880 \mu \mathrm{g}$ arm. The $440 \mu \mathrm{g}$ sirolimus was also significantly superior in achieving the secondary endpoint: VH score of 0 or $0.5+$ was achieved in $52.6 \%$ of patients in the $440 \mu \mathrm{g}$ arm as compared with $43.1 \%$ in the $880 \mu \mathrm{g}$ arm and $35 \%$ in the $44 \mu \mathrm{g}$ arm. BCVA was maintained overall in the first 5 months. Regarding the safety of sirolimus, 
Table 17 Studies on intravitreal methotrexate (demographics and clinical features)

\begin{tabular}{|c|c|c|c|c|c|c|c|c|}
\hline \multirow[t]{2}{*}{ Study } & \multirow{2}{*}{$\begin{array}{l}\text { Period } \\
\text { of study }\end{array}$} & \multirow{2}{*}{$\begin{array}{l}\text { Study } \\
\text { design }\end{array}$} & \multirow{2}{*}{$\begin{array}{l}\text { Study } \\
\text { duration }\end{array}$} & \multirow{2}{*}{$\begin{array}{l}\text { Number of } \\
\text { participants/ } \\
\text { eyes }\end{array}$} & \multicolumn{2}{|c|}{ Demographics } & \multicolumn{2}{|c|}{ Clinical features of participants } \\
\hline & & & & & $\begin{array}{l}\text { Age } \\
\text { (years) }\end{array}$ & $\begin{array}{l}\text { Sex } \\
\text { (female) }\end{array}$ & $\begin{array}{l}\text { Diagnosis of } \\
\text { study eye }\end{array}$ & Details \\
\hline $\begin{array}{l}\text { Taylor } \\
\text { et } \mathrm{al}^{37}\end{array}$ & - & $\begin{array}{l}\text { Prospective, } \\
\text { consecutive, } \\
\text { interventional } \\
\text { case series }\end{array}$ & $\begin{array}{l}\text { Follow-up } \\
\text { of } 6 \text { months } \\
\text { in } 80 \%\end{array}$ & $\begin{array}{l}\text { I5 eyes of } \\
15 \text { patients }\end{array}$ & $\begin{array}{l}50 \text { (range, } \\
25-68)\end{array}$ & $47 \%$ & $\begin{array}{l}\text { Active NIU } \pm \\
\text { CME, all steroid } \\
\text { responders }\end{array}$ & $\begin{array}{l}27 \% \text { anterior uveitis } \\
\text { with long-standing CME, } \\
53 \% \text { intermediate uveitis } \\
\text { with active vitritis and } \\
\text { CME, } 20 \% \text { panuveitis } \\
\text { with vitritis and CME }\end{array}$ \\
\hline $\begin{array}{l}\text { Taylor } \\
\text { et } \mathrm{al}^{38}\end{array}$ & - & $\begin{array}{l}\text { Multicenter, } \\
\text { retrospective } \\
\text { interventional } \\
\text { case series }\end{array}$ & $\begin{array}{l}\text { Mean } \\
\text { follow-up: } \\
\text { II.2 months } \\
\text { (range, 3-28 } \\
\text { months) }\end{array}$ & $\begin{array}{l}38 \text { eyes of } \\
30 \text { patients }\end{array}$ & $\begin{array}{l}\text { Median: } \\
46 \text { (range, } \\
20-73)\end{array}$ & $53 \%$ & NIU & $\begin{array}{l}\text { I8\% chronic anterior } \\
\text { uveitis with CME, } 42 \% \\
\text { intermediate uveitis } \\
\text { or pars planitis, } 39 \% \\
\text { posterior uveitis or } \\
\text { panuveitis }\end{array}$ \\
\hline
\end{tabular}

Note: “-”, data not available.

Abbreviations: CME, cystoid macular edema; CFT, central foveal thickness; CMT, central macular thickness; CRT, central retinal thickness; IVTA, intravitreal triamcinolone acetonide; logMAR, logarithm of Minimal Angle of Resolution; NIU, noninfectious uveitis; VA, visual acuity.

there was one case of culture-negative endophthalmitis in the $440 \mu \mathrm{g}$ arm and noninfectious endophthalmitis in $0.9 \%$ of patients in the $440 \mu \mathrm{g}$ arm and $3.4 \%$ of patients in the $880 \mu \mathrm{g}$ arm. There were also single cases of raised IOP, glaucoma, and cataract formation in the $44 \mu \mathrm{g}$ and $440 \mu \mathrm{g}$ arms. $^{42}$

In summary, based on the published literature, sirolimus appears to be effective in controlling intraocular inflammation and is well-tolerated regardless of the administration route. However, no significant effects were shown in improving BCVA or CMT. The results of currently ongoing studies may help us to establish the efficacy and side effect profile of intravitreal sirolimus.

\section{Intravitreal anti-tumor necrosis factor: infliximab}

Infliximab, an anti-tumor necrosis factor agent, is a chimeric monoclonal antibody biologic drug usually used systemically for the treatment of autoimmune diseases. Administering infliximab intravitreally eliminates the systemic side effects of the drug, which is ideal. These side effects include congestive heart failure, reactivation of latent tuberculosis, and increased risk

Table I 8 Studies on intravitreal methotrexate (outcomes)

\begin{tabular}{|c|c|c|c|c|c|c|}
\hline \multirow[t]{2}{*}{ Study } & \multirow{2}{*}{$\begin{array}{l}\text { Number of } \\
\text { participants/ } \\
\text { eyes }\end{array}$} & \multicolumn{3}{|l|}{ Intervention } & \multirow{2}{*}{$\begin{array}{l}\text { Numbers } \\
\text { excluding those } \\
\text { lost to follow- } \\
\text { up/dropout }\end{array}$} & \multirow{2}{*}{$\begin{array}{l}\text { Outcomes } \\
\text { measured } \\
\text { BCVA }\end{array}$} \\
\hline & & $\begin{array}{l}\text { Intravitreal } \\
\text { methotrexate }\end{array}$ & $\begin{array}{l}\text { Systemic } \\
\text { CS }\end{array}$ & Immunosuppression & & \\
\hline Taylor et $\mathrm{al}^{37}$ & $\begin{array}{l}15 \text { eyes of } \\
15 \text { patients }\end{array}$ & $400 \mathrm{~g}$ in $0.1 \mathrm{~mL}$ & $\begin{array}{l} \pm \text { (same as } \\
\text { baseline) }\end{array}$ & \pm & $\begin{array}{l}\text { I2 (3 lost at } \\
\text { different times for } \\
\text { different reasons) }\end{array}$ & $\begin{array}{l}\text { I week: } 0.82 \pm 0.13 \text {, } \\
\text { I month: } 0.73 \pm 0.12 \text {, } \\
3 \text { months: } 0.63 \pm 0.1 \mathrm{I} \\
6 \text { months: } 0.59 \pm 0.09 \\
(P<0.0 \text { I })\end{array}$ \\
\hline Taylor et $\mathrm{al}^{38}$ & $\begin{array}{l}38 \text { eyes of } \\
30 \text { patients }\end{array}$ & $400 \mathrm{~g}$ in $0.1 \mathrm{~mL}$ & $\begin{array}{l} \pm \text { (same as } \\
\text { baseline) }\end{array}$ & \pm & - & $\begin{array}{l}0.48 \text { (range, } \\
0.00-1.30)(P=0.000)\end{array}$ \\
\hline
\end{tabular}

Notes: “-”, data not available; \pm , treatment was or was not administered based on physician's discretion.

Abbreviations: BCVA, best-corrected visual acuity; CME, cystoid macular edema; CFT, central foveal thickness; CMT, central macular thickness; CRT, central retinal thickness; CS, corticosteroids; ME, macular edema. 


\begin{tabular}{|c|c|c|c|c|c|c|}
\hline $\begin{array}{l}\text { Laterality } \\
\text { of condition }\end{array}$ & Duration of uveitis & $\begin{array}{l}\text { Presence of } \\
\text { other ocular } \\
\text { conditions }\end{array}$ & $\begin{array}{l}\text { Previous uveitis } \\
\text { treatment }\end{array}$ & $\begin{array}{l}\text { Mean } \\
\text { baseline VA } \\
\text { (logMAR) }\end{array}$ & $\begin{array}{l}\text { Mean } \\
\text { baseline } \\
\text { vitreous haze }\end{array}$ & $\begin{array}{l}\text { Mean baseline } \\
\text { CRT/CFT/ } \\
\text { CMT }(\mu \mathrm{m})\end{array}$ \\
\hline $\begin{array}{l}100 \% \\
\text { unilateral }\end{array}$ & $\begin{array}{l}\text { Median duration of } \\
\text { CME in current disease } \\
\text { episode: } 6 \text { months } \\
\text { (range, } 1-54 \text { months) }\end{array}$ & $\begin{array}{l}20 \% \\
\text { vitrectomized } \\
\text { eyes, } 67 \% \\
\text { pseudophakic }\end{array}$ & $\begin{array}{l}47 \% \text { on systemic } \\
\text { medication at study } \\
\text { entry. } 27 \% \text { eyes had } \\
\text { previous IVTA injection }\end{array}$ & $1.06 \pm 0.12$ & $1.40 \pm 0.16$ & $425 \pm 57$ \\
\hline- & - & - & $\begin{array}{l}47 \% \text { on systemic } \\
\text { medication at time of } \\
\text { study entry }\end{array}$ & $\begin{array}{l}0.60 \text { (range, } \\
0.10-1.30 \text { ) }\end{array}$ & - & $\begin{array}{l}436 \pm 33 \text { (range, } \\
227-1,173 \text { ) }\end{array}$ \\
\hline
\end{tabular}

of infections. Intravenous infliximab is also contraindicated in patients such as those with a history of advanced congestive cardiac failure, active infections, or cancer. ${ }^{43}$

Limited trials are available for the use of intravitreal infliximab in NIU. To the best of our knowledge, there is only one study that fits our inclusion criteria. Markomichelakis et al performed a prospective, noncomparative interventional pilot study on the effect of intravitreal infliximab in the treatment of sight-threatening relapsing uveitis in Behçet's disease of 15 eyes. ${ }^{44}$ The study observed the effects of $1 \mathrm{mg} / 0.05 \mathrm{~mL}$ of infliximab up to 30 days posttreatment. Significant improvement in BCVA was noted by day 7 and was sustained until day 30. A decrease in intraocular inflammation and improvement in retinal vasculitis was maintained until day 30 . However, even though there was a decrease in mean CMT, persistent CME was noted in $80 \%$ of the eyes. There were no statistically significant differences between the results of those with and without baseline systemic immunosuppressants. No ocular or systemic side effects were observed during the course of 30 days; however, the study did not evaluate the possibility of retinal toxicity and autoantibodies that may have formed

\begin{tabular}{|c|c|c|c|c|c|c|}
\hline $\begin{array}{l}\text { Mean CRT/CFT/ } \\
\text { CMT }(\mu \mathrm{m})\end{array}$ & ME & $\begin{array}{l}\text { Uveitis activityl } \\
\text { vitreous haze } \\
\text { score }\end{array}$ & $\begin{array}{l}\text { Mean time to first } \\
\text { recurrence of uveitis }\end{array}$ & $\begin{array}{l}\text { Uveitis } \\
\text { recurrence rate }\end{array}$ & Reinjections & Others \\
\hline $\begin{array}{l}2 \text { months: } 299 \pm 55 \\
P=0.0 \mathrm{I}), 4 \text { months: } \\
29 \mathrm{I} \pm 53(P=0.0 \mathrm{I}), \\
6 \text { months: } 275 \pm 5 \mathrm{I} \\
(P=0.0 \mathrm{I})\end{array}$ & - & $\begin{array}{l}\text { I month: } 0.70 \pm 0.23 \\
(P=0.07), 3 \text { months: } \\
0.50 \pm 0.17(P=0.05), \\
6 \text { months: } 0.25 \pm 0.18 \\
(P=0.01)\end{array}$ & $\begin{array}{l}\text { Median } 4.0 \text { months } \\
\text { (range, I-4 months) }\end{array}$ & - & $\begin{array}{l}27 \% \text { had repeat injections } \\
\text { after relapse. All gained } \\
\text { median of } 17 \text { letters } \\
\text { (range, } 6-23 \text { letters) by } \\
2 \text { months after reinjection }\end{array}$ & \\
\hline $\begin{array}{l}363 \pm 25 \text { (range, } \\
150-826) \\
(P=0.001)\end{array}$ & - & - & $\begin{array}{l}21 \% \text { eyes relapsed at } \\
\text { median } 3 \text { months (range, } \\
1-17 \text { months). } 58 \% \\
\text { of eyes in extended } \\
\text { period of remission: } \\
\text { Kaplan-Meier estimate is } \\
17 \text { months to recurrence }\end{array}$ & - & - & $\begin{array}{l}57 \% \text { reduced } \\
\text { dose of } \\
\text { systemic } \\
\text { medication. } 20 \% \\
\text { still require at } \\
\text { final follow-up }\end{array}$ \\
\hline
\end{tabular}


Table 19 Studies on intravitreal methotrexate (adverse effects)

\begin{tabular}{|c|c|c|c|c|c|c|c|c|c|}
\hline \multirow[t]{4}{*}{ Study } & \multirow{4}{*}{$\begin{array}{l}\text { Number of } \\
\text { participants/ } \\
\text { eyes }\end{array}$} & \multicolumn{3}{|l|}{ Intervention } & \multicolumn{5}{|l|}{ Adverse events } \\
\hline & & \multirow{3}{*}{$\begin{array}{l}\text { Intravitreal } \\
\text { methotrexate }\end{array}$} & \multirow{3}{*}{$\begin{array}{l}\text { Systemic } \\
\text { CS }\end{array}$} & \multirow[t]{3}{*}{ Immunosuppression } & \multicolumn{4}{|l|}{ Ocular } & \multirow{3}{*}{ Systemic } \\
\hline & & & & & \multirow[t]{2}{*}{ Cataracts } & \multicolumn{2}{|l|}{ Raised IOP } & \multirow[t]{2}{*}{ Others } & \\
\hline & & & & & & $\begin{array}{l}>10 \mathrm{mmHg} / \\
\text { requiring } \\
\text { medications }\end{array}$ & $\begin{array}{l}\text { Requiring } \\
\text { surgery }\end{array}$ & & \\
\hline $\begin{array}{l}\text { Taylor } \\
\text { et } \mathrm{al}^{37}\end{array}$ & $\begin{array}{l}15 \text { eyes of } \\
15 \text { patients }\end{array}$ & $400 \mathrm{~g}$ in $0.1 \mathrm{~mL}$ & $\begin{array}{l} \pm \text { (same as } \\
\text { baseline) }\end{array}$ & \pm & $\begin{array}{l}6.7 \% \text { (thought } \\
\text { unlikely to be due } \\
\text { to methotrexate) }\end{array}$ & None & & None & $\begin{array}{l}6.7 \% \text { corneal } \\
\text { epitheliopathy }\end{array}$ \\
\hline $\begin{array}{l}\text { Taylor } \\
\text { et } \mathrm{al}^{38}\end{array}$ & $\begin{array}{l}38 \text { eyes of } \\
30 \text { patients }\end{array}$ & $400 \mathrm{~g}$ in $0.1 \mathrm{~mL}$ & $\begin{array}{l} \pm \text { (same as } \\
\text { baseline) }\end{array}$ & \pm & None & None & $3 \%$ & None & None \\
\hline
\end{tabular}

Note: \pm , treatment was or was not administered based on physician's discretion.

Abbreviations: IOP, intraocular pressure; CS, corticosteroids.

as a response to intravitreal infliximab. This potential immunogenic and retinotoxic effect was previously reported in a study on low-dose $(0.05 \mathrm{mg})$ intravitreal administration of infliximab in eyes with age-related macular degeneration and CNV. ${ }^{45}$ Furthermore, as the follow-up was only for 30 days, the long-term effects of intravitreal infliximab and the effects of repeated injections are not known. The small sample size was also a limitation.

Markomichelakis et al also noted that based on a similar study performed by their group regarding the effect of intravenous administration of infliximab, the intravenous route seemed to have a significantly faster effect as compared with the intravitreal route. ${ }^{46}$ This was postulated to be due to the systemic nature of Behçet's disease. Therefore, it was recommended that intravitreal injections be considered only when there are systemic side effects or contraindications to the intravenous route. Due to various factors related to intravitreal infliximab such as retinotoxicity, there has been less enthusiasm to pursue this agent using the intravitreal route for NIU. Large-scale and long-term studies are required to establish the safety and efficacy profile of these drugs. It is also important to recognize that drugs that are deemed tolerable via systemic administration may not be well-tolerated intravitreally.

\section{Intravitreal nonsteroidal anti- inflammatory drugs}

Nonsteroidal anti-inflammatory drugs are commonly used systemically for their analgesic and also anti-inflammatory effects. ${ }^{47}$ Furthermore, the risks of cataract formation or increased IOP are not known. Therefore, the ability of the intravitreal injections to deliver the drug at potentially

Table 20 Studies on intravitreal sirolimus (demographics)

\begin{tabular}{|c|c|c|c|c|c|c|c|c|}
\hline \multirow[t]{2}{*}{ Study } & \multirow{2}{*}{$\begin{array}{l}\text { Period } \\
\text { of study }\end{array}$} & \multirow[t]{2}{*}{ Study design } & \multirow{2}{*}{$\begin{array}{l}\text { Study } \\
\text { duration }\end{array}$} & \multicolumn{2}{|c|}{ Number of participants } & \multicolumn{3}{|c|}{ Demographics } \\
\hline & & & & & & $\begin{array}{l}\text { Age } \\
\text { (years) }\end{array}$ & $\begin{array}{l}\text { Sex } \\
\text { (female) }\end{array}$ & Ethnicity \\
\hline Ibrahim et al ${ }^{39}$ & - & $\begin{array}{l}\text { Prospective, randomized, } \\
\text { open-label, interventional } \\
\text { study }\end{array}$ & 12 months & 15 eyes & $\begin{array}{l}20 \% \text { cat I } \\
\text { (active uveitis) } \\
60 \% \text { cat } 2 \\
\text { (active uveitis) } \\
20 \% \text { cat } 3 \\
\text { (inactive uveitis) }\end{array}$ & $45 \pm 19.8$ & $40 \%$ & $\begin{array}{l}\text { 73\% Caucasian, } 20 \% \\
\text { African-American, } \\
7 \% \text { others }\end{array}$ \\
\hline \multirow[t]{2}{*}{ Sepah et $\mathrm{al}^{40}$} & Ongoing & $\begin{array}{l}\text { Randomized, phase } 2 \text {, } \\
\text { open-label study }\end{array}$ & 6 months & 25 eyes & $\begin{array}{l}\text { I I ( } 440 \mu g \\
\text { injection every } \\
\text { month) }\end{array}$ & $40 \pm 18.53$ & $55 \%$ & I00\% white \\
\hline & & & & & $\begin{array}{l}\text { I } 4(880 \mu g \\
\text { injection every } \\
\text { month) }\end{array}$ & $53 \pm 14.09$ & $86 \%$ & $\begin{array}{l}93 \% \text { white, } 7 \% \\
\text { Hispanic }\end{array}$ \\
\hline Srivastava ${ }^{42}$ & Ongoing & $\begin{array}{l}\text { Multicenter, randomized, } \\
\text { double-masked phase III } \\
\text { studies }\end{array}$ & 5 months & 347 eyes & & $\geq 18$ & $60 \%$ & - \\
\hline
\end{tabular}

Note: “-”, data not available.

Abbreviation: cat, category. 


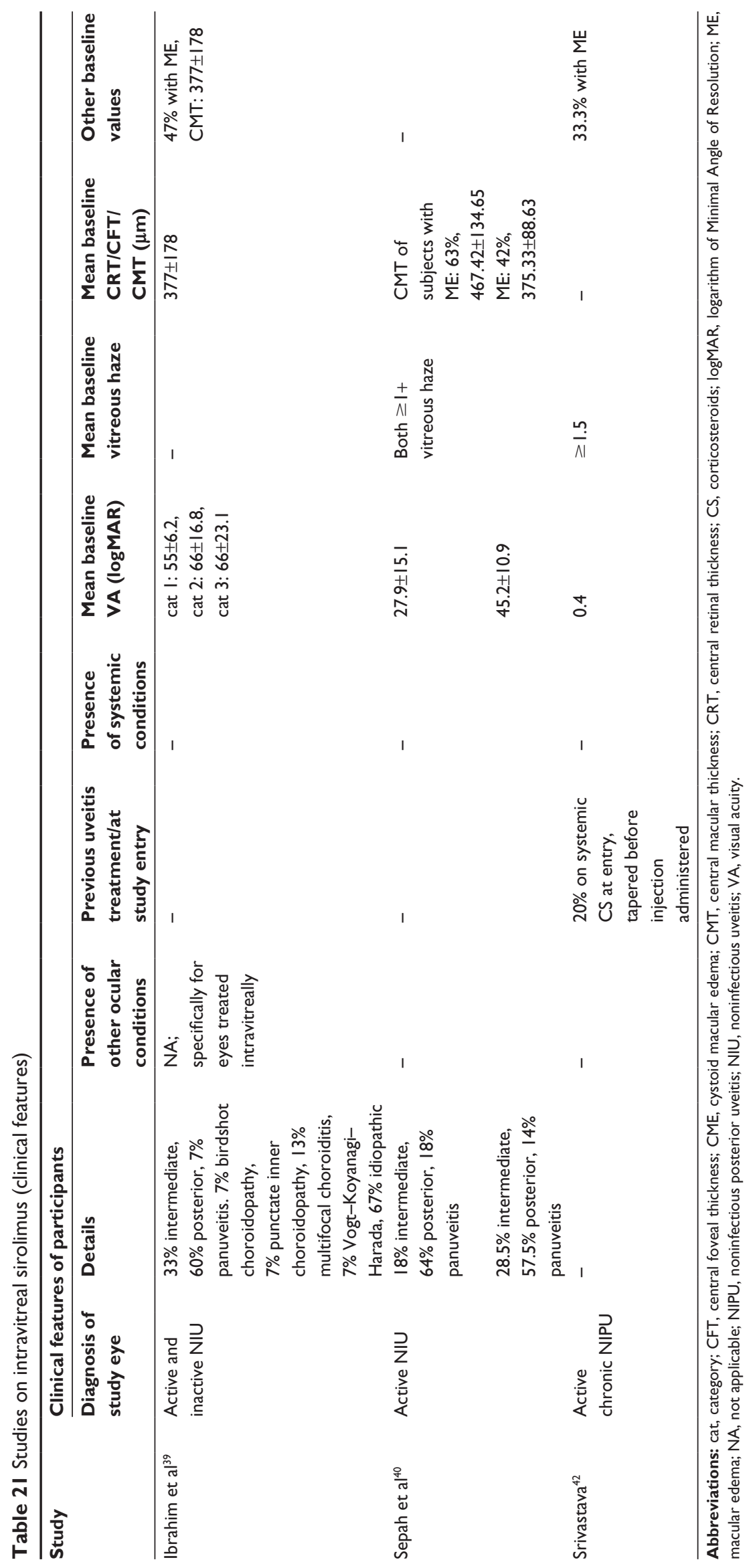


Table 22 Studies on intravitreal sirolimus (outcomes)

\begin{tabular}{|c|c|c|c|c|c|c|c|}
\hline \multirow[t]{2}{*}{ Study } & \multirow{2}{*}{\multicolumn{2}{|c|}{$\begin{array}{l}\text { Number of } \\
\text { participants }\end{array}$}} & \multicolumn{3}{|l|}{ Intervention } & \multirow{2}{*}{$\begin{array}{l}\text { Numbers } \\
\text { excluding those } \\
\text { lost to follow-up/ } \\
\text { dropout }\end{array}$} & \multirow{2}{*}{$\begin{array}{l}\text { Outcomes measured } \\
\text { BCVA }\end{array}$} \\
\hline & & & $\begin{array}{l}\text { Intravitreal } \\
\text { sirolimus }\end{array}$ & $\begin{array}{l}\text { Systemic } \\
\text { CS }\end{array}$ & Immunosuppression & & \\
\hline \multirow[t]{3}{*}{ Ibrahim et al ${ }^{39}$} & 15 eyes & $\begin{array}{l}20 \% \text { cat I } \\
\text { (active uveitis) }\end{array}$ & $352 \mu \mathrm{g}$ & - & - & 14 & $\begin{array}{l}\text { No statistically significant } \\
\text { change from baseline }\end{array}$ \\
\hline & & $\begin{array}{l}60 \% \text { cat } 2 \\
\text { (active uveitis) }\end{array}$ & & $\begin{array}{l}\mathrm{CS} \geq 10 \\
\mathrm{mg} / \text { day }\end{array}$ & - & & \\
\hline & & $\begin{array}{l}20 \% \text { cat } 3 \\
\text { (inactive uveitis) }\end{array}$ & & $\begin{array}{l} \pm \mathrm{CS}<10 \\
\mathrm{mg} / \text { day }\end{array}$ & \pm & & \\
\hline \multirow[t]{2}{*}{ Sepah et al ${ }^{40}$} & 25 eyes & 11 & $\begin{array}{l}440 \mu g \\
\text { monthly }\end{array}$ & \pm & \pm & - & $\begin{array}{l}\text { Mean change: }+3.66 \\
\text { ETDRS letters }\end{array}$ \\
\hline & & 14 & $\begin{array}{l}880 \mu \mathrm{g} \text { every } \\
2 \text { months }\end{array}$ & \pm & \pm & - & $\begin{array}{l}\text { Mean change: }-2.91 \\
\text { EDTRS letters }\end{array}$ \\
\hline Srivastava ${ }^{42}$ & 347 eyes & & $\begin{array}{l}44 \mu g \text { or } \\
440 \mu g \text { or } \\
880 \mu g \text { or } \\
440 \mu g \text { every } \\
2 \text { months }\end{array}$ & \pm & \pm & $95 \%$ & $\begin{array}{l}\text { Baseline } \mathrm{BCVA} \geq 20 / 40 \text { : } \\
\text { little improvement, } \\
\text { baseline }<20 / 40 \text { : gained } \\
5 \text { letters ( } 440 \mu \mathrm{g} \text { and } \\
44 \mu \mathrm{g}) \text {, baseline }<20 / 100 \text { : } \\
10.5 \text { letters in } 440 \mu \mathrm{g} \text { vs } \\
4.5 \text { in controls }\end{array}$ \\
\hline
\end{tabular}

Notes: “-”, data not available; \pm , treatment was or was not administered based on physician's discretion.

Abbreviations: BCVA, best-corrected visual acuity; cat; category; CFT, central foveal thickness; CMT, central macular thickness; CRT, central retinal thickness; CS, corticosteroids; ETDRS, Early Treatment Diabetic Retinopathy Study; ME, macular edema.

Table 23 Studies on intravitreal sirolimus (adverse effects)

\begin{tabular}{llll}
\hline Study & Number of participants & Intervention & \\
\cline { 3 - 5 } & Intravitreal sirolimus & Systemic CS & Immunosuppression
\end{tabular}

\begin{tabular}{|c|c|c|c|c|c|}
\hline \multirow[t]{3}{*}{ Ibrahim et al ${ }^{39}$} & 15 eyes & $\begin{array}{l}20 \% \text { cat I } \\
\text { (active uveitis) }\end{array}$ & $352 \mu \mathrm{g}$ & - & - \\
\hline & & $\begin{array}{l}60 \% \text { cat } 2 \\
\text { (active uveitis) }\end{array}$ & & $\mathrm{CS} \geq 10 \mathrm{mg} /$ day & - \\
\hline & & $\begin{array}{l}20 \% \text { cat } 3 \\
\text { (inactive uveitis) }\end{array}$ & & $\pm \mathrm{CS}<10 \mathrm{mg} / \mathrm{day}$ & \pm \\
\hline \multirow[t]{2}{*}{ Sepah et $\mathrm{a}^{40}$} & 25 eyes & II & $440 \mu \mathrm{g}$ monthly & \pm & \pm \\
\hline & & 14 & $880 \mu \mathrm{g}$ every 2 months & \pm & \pm \\
\hline Srivastava ${ }^{42}$ & 347 eyes* & & $\begin{array}{l}44 \mu \mathrm{g} \text { or } 440 \mu \mathrm{g} \text { or } \\
880 \mu \mathrm{g} \text { or } 440 \mu \mathrm{g} \\
\text { every } 2 \text { months }\end{array}$ & \pm & \pm \\
\hline
\end{tabular}

Notes: *Data from both intravitreal and subconjunctival administration. “-”, data not available; \pm , treatment was or was not administered based on physician's discretion. Abbreviations: CS, corticosteroids; IOP, intraocular pressure. 
Mean CRT/CFT/CMT $(\mu \mathrm{m})$

Patients without ME: CMT did not change *Patients with ME at baseline: mean change of 105 at month 6, 106 at month 12 (not statistically significant) Patient with ME at baseline: mean change of -30 at month 6 and -47 at month 12 (changes are not statistically significant)

$-$

Mean change in CFT in those with ME: -89.42

Mean change in CFT in those with ME: +81.5

Minimal change in those with ME at baseline

\section{Uveitis activity/vitreous haze score \\ Reinjections \\ Others}

6 months: $40 \%$ showed reduction

70 injections

in 14 eyes

steps vitreous haze, $60 \%$ no change

or reduction of one step. 12 months: $70 \%$

reduction of $\geq 2$ steps, $0 \%$ with increase in

vitreous haze $(P<0.05$, month 12$)$

6 months and 12 months: $88 \%$ no

change or a reduction of one step of

vitreous haze. At month 12: 12\% showed

worsening of one step $(P>0.05)$

Decreased $\geq$ I step: $81.8 \%, \geq 2$ steps:

$63.6 \%$

Decreased $\geq$ I step: $92.9 \%$ (no statistically significant difference in 2 groups, $P=0.564$ ), $\geq 2$ steps: $50 \%(P=0.695)$

Vitreous haze score of $0: 22.8 \%$ in $440 \mu \mathrm{g}, 16.4 \%$ in $880 \mu \mathrm{g}, 10.3 \%$ in $44 \mu \mathrm{g}$. $(P=0.025)$, vitreous haze score of 0 or $0.5+: 52.6 \% 440 \mu \mathrm{g}, 35 \% 44 \mu \mathrm{g}, 43.1 \% 880$ $\mu \mathrm{g}(P=0.008)$
Tapering systemic CS: $76.9 \%$ in $440 \mu \mathrm{g}$ arm, $63.6 \%$ in $44 \mu \mathrm{g}$ arm

\begin{tabular}{|c|c|c|c|c|}
\hline \multicolumn{5}{|c|}{ Adverse events } \\
\hline \multicolumn{4}{|l|}{ Ocular } & \multirow[t]{3}{*}{ Systemic } \\
\hline \multirow[t]{2}{*}{ Cataracts } & \multicolumn{2}{|l|}{ Raised IOP } & \multirow[t]{2}{*}{ Others } & \\
\hline & $\begin{array}{l}>10 \mathrm{mmHg} / \\
\text { requiring } \\
\text { medications }\end{array}$ & $\begin{array}{l}\text { Requiring } \\
\text { surgery }\end{array}$ & & \\
\hline $14.30 \%$ & $\begin{array}{l}\text { One case IOP } \\
>25 \mathrm{mmHg}\end{array}$ & None & Postulated to be unrelated to drug: vitreous floaters & None \\
\hline- & - & - & - & - \\
\hline Single cases & \multicolumn{2}{|c|}{ Single cases in $44 \mu \mathrm{g}$ and $440 \mu \mathrm{g}$ arms } & $\begin{array}{l}\text { One case of culture-negative endophthalmitis in } 440 \mu \mathrm{g} \text { arm. } \\
\text { Noninfectious endophthalmitis: } 0.9 \% \text { patients' } 440 \mu \mathrm{g}, 3.4 \% \\
\text { patients in the } 880 \mu \mathrm{g} \text { arm }\end{array}$ & - \\
\hline
\end{tabular}


efficacious levels straight to the posterior segment without the side effects of lens opacification and increased IOP is a favorable prospect. However, to the best of our knowledge, there has been only one trial performed with regard to the use of intravitreal nonsteroidal anti-inflammatory drugs in NIU that fulfills our inclusion criteria.

A pilot randomized comparative clinical trial by Soheilian et al compared the efficacy and safety of $500 \mathrm{mg} / 0.1 \mathrm{~mL}$ of intravitreal diclofenac (IVD) as opposed to $2 \mathrm{mg}$ of IVTA in the treatment of CME in 15 uveitic eyes. ${ }^{48}$ Both IVD and IVTA showed improvement in BCVA and CMT; however, the improvement in eyes treated with IVTA was statistically significant, whereas the improvement in eyes treated with IVD was not statistically significant. However, there were no statistically significant differences when comparing the mean BCVA and CMT values of the two. The only adverse effect observed in this study was cataract formation; $12.5 \%$ in IVD and $28.5 \%$ in IVT. This did not reach statistical significance. From this study, it appears that IVD is not as effective as IVTA in the treatment of uveitic CME. However, IVD may still have the potential of being an alternative to IVTA in steroid responders.

\section{Emerging drug therapies}

The use of gene therapy in the treatment of NIU is an exciting prospect. Intravitreal delivery of adeno-associated viral vectors coupled with genes can be used as antiinflammatory proteins. Some of these agents are AAV-TatNrf2mer, AAV2/2-tetON-vIL-10, AAV-CARD, and AAV-sGFP-TatM013. These agents have been shown to have anti-inflammatory effects in the eyes of mice. ${ }^{49-52}$ Therefore, this could be potentially useful in NIU given that inflammation is the primary pathology.

New-generation calcineurin inhibitor, voclosporin showed a potential reduction in the $\mathrm{VH}$ in $50 \%$ of patients along with the reduction in the oral prednisolone therapy. However, the phase III study did not show a significant difference between the placebo and disease groups. ${ }^{53,54}$ The possible reason could be due to the oral route of administration; therefore, it will be worthwhile to study the efficacy after local ocular administration. In line, there are several monoclonal antibodies such as secukinumab, gevokizumab, taclizumab, sarilumab, ESBA 105, rituximab, daclizumab, alemtuzumab, adalimumab, abatacept, etanercept, and rilonacept that are under various phase trials for treating uveitis. ${ }^{54}$

Another interesting prospect would be the advancement of drug delivery methods for the treatment of retinal diseases such as suprachoroidal drug delivery methods.
Delivering drugs through the suprachoroidal space (such as triamcinolone acetonide) potentially allows for an increased amount of drugs to bypass the sclera and diffuse into the posterior segment without the risk that comes with intraocular injections..$^{55}$

\section{Conclusion}

Intravitreal injections are an effective alternative to systemic medications as they are able to avoid systemic side effects but achieve a therapeutic dose in the vitreous. As covered in the review, there are a multitude of different drugs that can be used intravitreally for the treatment of NIU. However, it is difficult to compare the drugs with a lack of comparative studies. Furthermore, each drug appears to be advantageous in targeting certain sequelae or complications of NIU. Therefore, the use of the intravitreal drug should be largely customized to each individual patient with the calculation of risk/benefit ratio when deciding between various intravitreal, systemic, and local therapies. Ideally, we would have liked to evaluate the cost-effectiveness of each drug, as we believe that it is an important factor in the decision-making process.

Finally, systemic treatment still has an important role in treating NIU associated with systemic conditions such as sarcoidosis, autoimmune disease, and Behçet's disease and also for most cases of bilateral, symmetric, disease.

\section{Acknowledgment}

Dr Rupesh Agrawal was sponsored by Clinician Scientist career scheme, National Healthcare Group, Singapore for clinician scientist career track.

\section{Disclosure}

The authors report no conflicts of interest in this work.

\section{References}

1. Multicenter Uveitis Steroid Treatment Trial Research Group, Kempen JH, Altaweel MM, et al. Benefits of systemic anti-inflammatory therapy versus fluocinolone acetonide intraocular implant for intermediate uveitis, posterior uveitis, and panuveitis: fifty-four-month results of the multicenter uveitis steroid treatment (MUST) trial and follow-up study. Ophthalmology. 2015;122(10):1967-1975.

2. Lee DJ. Intraocular implants for the treatment of autoimmune uveitis. $J$ Funct Biomater. 2015;6(3):650-666.

3. Weiner A, BenEzra D. Clinical patterns and associated conditions in chronic uveitis. Am J Ophthalmol. 1991;112(2):151-158.

4. Rothova A, Suttorp-van Schulten MS, Frits Treffers W, Kijlstra A. Causes and frequency of blindness in patients with intraocular inflammatory disease. Br J Ophthalmol. 1996;80(4):332-336.

5. Pasadhika S, Rosenbaum JT. Update on the use of systemic biologic agents in the treatment of noninfectious uveitis. Biologics. 2014;8:67-81.

6. McDonough AK, Curtis JR, Saag KG. The epidemiology of glucocorticoid-associated adverse events. Curr Opin Rheumatol. 2008;20(2): 131-137. 
7. Morrison PW, Khutoryanskiy VV. Advances in ophthalmic drug delivery. Ther Deliv. 2014;5(12):1297-1315.

8. Kok H, Lau C, Maycock N, McCluskey P, Lightman S. Outcome of intravitreal triamcinolone in uveitis. Ophthalmology. 2005;112(11):1916. e1911-e1917.

9. Park UC, Park JH, Yu HG. Long-term outcome of intravitreal triamcinolone acetonide injection for the treatment of uveitis attacks in Behcet disease. Ocul Immunol Inflamm. 2014;22(1):27-33.

10. Tuncer S, Yilmaz S, Urgancioglu M, Tugal-Tutkun I. Results of intravitreal triamcinolone acetonide (IVTA) injection for the treatment of panuveitis attacks in patients with Behcet disease. J Ocul Pharmacol Ther. 2007;23(4):395-401.

11. Sallam A, Taylor SR, Habot-Wilner Z, et al. Repeat intravitreal triamcinolone acetonide injections in uveitic macular oedema. Acta Ophthalmol. 2012;90(4):e323-e325.

12. Retisert. Available from: http://www.psivida.com/products-retisert. html. Accessed April 6, 2016.

13. Multicenter Uveitis Steroid Treatment Trial Research Group, Kempen JH, Altaweel MM, et al. Randomized comparison of systemic anti-inflammatory therapy versus fluocinolone acetonide implant for intermediate, posterior, and panuveitis: the multicenter uveitis steroid treatment trial. Ophthalmology. 2011;118(10):1916-1926.

14. Friedman DS, Holbrook JT, Ansari H, et al. Risk of elevated intraocular pressure and glaucoma in patients with uveitis: results of the multicenter uveitis steroid treatment trial. Ophthalmology. 2013;120(8): 1571-1579.

15. Pavesio C, Zierhut M, Bairi K, Comstock TL, Usner DW; Fluocinolone Acetonide Study Group. Evaluation of an intravitreal fluocinolone acetonide implant versus standard systemic therapy in noninfectious posterior uveitis. Ophthalmology. 2010;117(3):567-575, 575.e561.

16. Callanan DG, Jaffe GJ, Martin DF, Pearson PA, Comstock TL. Treatment of posterior uveitis with a fluocinolone acetonide implant: three-year clinical trial results. Arch Ophthalmol. 2008;126(9): 1191-1201.

17. Bollinger K, Kim J, Lowder CY, Kaiser PK, Smith SD. Intraocular pressure outcome of patients with fluocinolone acetonide intravitreal implant for noninfectious uveitis. Ophthalmology. 2011;118(10): 1927-1931.

18. Jaffe GJ. Reimplantation of a fluocinolone acetonide sustained drug delivery implant for chronic uveitis. Am J Ophthalmol. 2008;145(4): 667-675.

19. Multicenter Uveitis Steroid Treatment Trial Research Group, Sugar EA, Holbrook JT, et al. Cost-effectiveness of fluocinolone acetonide implant versus systemic therapy for noninfectious intermediate, posterior, and panuveitis. Ophthalmology. 2014;121(10):1855-1862.

20. Lowder C, Belfort R Jr, Lightman S, et al. Dexamethasone intravitreal implant for noninfectious intermediate or posterior uveitis. Arch Ophthalmol. 2011;129(5):545-553.

21. Khurana RN, Porco TC. Efficacy and safety of dexamethasone intravitreal implant for persistent uveitic cystoid macular edema. Retina. 2015;35(8):1640-1646.

22. Lam W, Albiani DA, Yoganathan P, et al. Real-world assessment of intravitreal dexamethasone implant $(0.7 \mathrm{mg})$ in patients with macular edema: the CHROME study. Clin Ophthalmol. 2015;9: $1255-1268$.

23. Tomkins-Netzer O, Taylor SR, Bar A, et al. Treatment with repeat dexamethasone implants results in long-term disease control in eyes with noninfectious uveitis. Ophthalmology. 2014;121(8):1649-1654.

24. Ryder SJ, Iannetta D, Bhaleeya SD, Kiss S. Efficacy and tolerability of bilateral sustained-release dexamethasone intravitreal implants for the treatment of noninfectious posterior uveitis and macular edema secondary to retinal vein occlusion. Clin Ophthalmol. 2015;9: 1109-1116.

25. Arcinue CA, Ceron OM, Foster CS. A comparison between the fluocinolone acetonide (Retisert) and dexamethasone (Ozurdex) intravitreal implants in uveitis. J Ocul Pharmacol Ther. 2013;29(5):501-507.
26. Sanford M. Fluocinolone acetonide intravitreal implant (Iluvien ${ }^{\circledR}$ ). Drugs. 2013;73(2):187-193.

27. Barry RJ, Nguyen QD, Lee RW, Murray PI, Denniston AK. Pharmacotherapy for uveitis: current management and emerging therapy. Clin Ophthalmol. 2014;8:1891-1911.

28. Mansour AM, Arevalo JF, Fardeau C, et al. Three-year visual and anatomic results of administrating intravitreal bevacizumab in inflammatory ocular neovascularization. Can J Ophthalmol. 2012;47(3): 269-274.

29. Julián K, Terrada C, Fardeau C, et al. Intravitreal bevacizumab as first local treatment for uveitis-related choroidal neovascularization: longterm results. Acta Ophthalmol. 2011;89(2):179-184.

30. Rouvas A, Petrou P, Douvali M, et al. Intravitreal ranibizumab for the treatment of inflammatory choroidal neovascularization. Retina. 2011;31(5):871-879.

31. Jeon S, Lee WK, Jung Y. Changes in the intraocular cytokine levels after intravitreal bevacizumab in uveitic macular edema. Ocul Immunol Inflamm. 2012;20(5):360-364.

32. Rahimi M, Shahrzad SS, Banifatemi M. Comparison of intravitreal injection of bevacizumab and triamcinolone acetonide in the treatment of uveitic macular edema. Iran J Immunol. 2012;9(2):136-144.

33. Reddy AK, Cabrera M, Yeh S, Davis JL, Albini TA. Optical coherence tomography-guided ranibizumab injection for cystoid macular edema in well-controlled uveitis: twelve-month outcomes. Retina. 2014; 34(12):2431-2438.

34. Mansour AM, Mackensen F, Arevalo JF, et al. Intravitreal bevacizumab in inflammatory ocular neovascularization. Am J Ophthalmol. 2008; 146(3):410-416.

35. Mansour AM, Arevalo JF, Ziemssen F, et al. Long-term visual outcomes of intravitreal bevacizumab in inflammatory ocular neovascularization. Am J Ophthalmol. 2009;148(2):310-316.e2.

36. Bae JH, Lee CS, Lee SC. Efficacy and safety of intravitreal bevacizumab compared with intravitreal and posterior sub-tenon triamcinolone acetonide for treatment of uveitic cystoid macular edema. Retina. 2011; 31(1):111-118.

37. Taylor SR, Habot-Wilner Z, Pacheco P, Lightman SL. Intraocular methotrexate in the treatment of uveitis and uveitic cystoid macular edema. Ophthalmology. 2009;116(4):797-801.

38. Taylor SR, Banker A, Schlaen A, et al. Intraocular methotrexate can induce extended remission in some patients in noninfectious uveitis. Retina. 2013;33(10):2149-2154.

39. Ibrahim MA, Sepah YJ, Watters A, et al. One-year outcomes of the SAVE study: sirolimus as a therapeutic approach for uveitis. Transl Vis Sci Technol. 2015;4(2):4.

40. Sepah YJ, Sadiq MA, Soliman MK, et al. Interim analyses of the SAVE-2 study: sirolimus as a therapeutic approach for uveitis: a phase 2, open-label, randomized study to assess the safety, tolerability, and bioactivity of two doses of intravitreal injection of sirolimus in patients with non-infectious uveitis. Invest Ophthalmol Vis Sci. 2015; 56(7):5775.

41. Merrill P, Nguyen QD, Clark WL, et al. The SAKURA study, a phase iii, multicenter, randomized, double-masked, study of intravitreal injections of DE-109 for the treatment of active, noninfectious uveitis of the posterior segment: baseline ocular disease characteristics. Invest Ophthalmol Vis Sci. 2014;55(13):109.

42. Srivastava SK. Study assessing double-masked uveitis treatment (SAKURA) phase 3 trial. Paper presented at: American Academy of Ophthalmology 2014 Annual Meeting; October 17-21, 2014; Chicago, IL.

43. Sfikakis PP. The first decade of biologic TNF antagonists in clinical practice: lessons learned, unresolved issues and future directions. Curr Dir Autoimmun. 2010;11:180-210.

44. Markomichelakis N, Delicha E, Masselos S, Sfikakis PP. Intravitreal infliximab for sight-threatening relapsing uveitis in Behçet disease: a pilot study in 15 patients. Am J Ophthalmol. 2012;154(3):534-541.e1.

45. Giganti MM. Adverse events after intravitreal infliximab (Remicade). Retina. 2010;30(1):71-80. 
46. Markomichelakis N, Delicha E, Masselos S, Fragiadaki K, Kaklamanis P, Sfikakis PP. A single infliximab infusion vs corticosteroids for acute panuveitis attacks in Behçet's disease: a comparative 4-week study. Rheumatology. 2011;50(3):593-597.

47. Kim SJ, Flach AJ, Jampol LM. Nonsteroidal anti-inflammatory drugs in ophthalmology. Surv Ophthalmol. 2010;55(2):108-133.

48. Soheilian M, Eskandari A, Ramezani A, Rabbanikhah Z, Soheilian R. A pilot study of intravitreal diclofenac versus intravitreal triamcinolone for uveitic cystoid macular edema. Ocul Immunol Inflamm. 2013; 21(2):124-129.

49. Smith JR, Verwaerde C, Rolling F, et al. Tetracycline-inducible viral interleukin-10 intraocular gene transfer, using adeno-associated virus in experimental autoimmune uveoretinitis. Hum Gene Therapy. 2005; 16(9):1037-1046.

50. Ildefonso CJ, Jaime H, Biswal MR, et al. Gene therapy with the caspase activation and recruitment domain reduces the ocular inflammatory response. Mol Ther. 2015;23(5):875-884.
51. Ildefonso CJ, Jaime H, Brown EE, et al. Targeting the Nrf2 signaling pathway in the retina with a gene-delivered secretable and cell-penetrating peptideocular gene delivery of an Nrf2-derived peptide. Invest Ophthalmol Vis Sci. 2016;57(2):372-386.

52. Ildefonso CJ, Jaime H, Rahman MM, et al. Gene delivery of a viral anti-inflammatory protein to combat ocular inflammation. Hum Gene Ther. 2015;26(1):59-68.

53. Anglade E, Aspeslet LJ, Weiss SL. A new agent for the treatment of noninfectious uveitis: rationale and design of three LUMINATE (Lux Uveitis Multicenter Investigation of a New Approach to Treatment) trials of steroid-sparing voclosporin. Clin Ophthalmol. 2008;2(4):693-702.

54. Maya JR, Sadiq MA, Zapata LJ, et al. Emerging therapies for noninfectious uveitis: what may becoming to the clinics. J Ophthalmol. 2014;2014:310329.

55. Moisseiev E, Loewenstein A, Yiu G. The suprachoroidal space: from potential space to a space with potential. Clin Ophthalmol. 2016;10: $173-178$.
Clinical Ophthalmology

\section{Publish your work in this journal}

Clinical Ophthalmology is an international, peer-reviewed journal covering all subspecialties within ophthalmology. Key topics include: Optometry; Visual science; Pharmacology and drug therapy in eye diseases; Basic Sciences; Primary and Secondary eye care; Patient Safety and Quality of Care Improvements. This journal is indexed on

\section{Dovepress}

PubMed Central and CAS, and is the official journal of The Society of Clinical Ophthalmology (SCO). The manuscript management system is completely online and includes a very quick and fair peer-review system, which is all easy to use. Visit http://www.dovepress.com/ testimonials.php to read real quotes from published authors. 